\title{
Article
}

\section{CpCo(III) Precatalysts for [2+2+2] Cycloadditions}

\author{
Fabian Fischer ${ }^{1}$, Michael Eder ${ }^{2}$ and Marko Hapke ${ }^{1,2, *(\mathbb{D}}$ \\ 1 Leibniz-Institut für Katalyse e.V. (LIKAT), Albert-Einstein-Strasse 29a, D-18059 Rostock, Germany; \\ fabian.fischer@catalysis.de \\ 2 Institut für Katalyse (INCA), Johannes Kepler Universität Linz, Altenberger Strasse 69, A-4040 Linz, Austria; \\ michael-eder@gmx.net \\ * Correspondence: marko.hapke@jku.at
}

check for

updates

Citation: Fischer, F.; Eder, M.; Hapke, M. CpCo(III) Precatalysts for $[2+2+2]$ Cycloadditions. Catalysts 2021, 11, 596. https://doi.org/10.3390/ catal11050596

Academic Editors: Jose

R. Cabrero-Antonino and Rosa Adam

Received: 12 April 2021

Accepted: 2 May 2021

Published: 4 May 2021

Publisher's Note: MDPI stays neutral with regard to jurisdictional claims in published maps and institutional affiliations.

Copyright: (c) 2021 by the authors. Licensee MDPI, Basel, Switzerland. This article is an open access article distributed under the terms and conditions of the Creative Commons Attribution (CC BY) license (https:// creativecommons.org/licenses/by/ $4.0 /)$.

\begin{abstract}
Catalysts applied in cobalt-catalyzed cyclotrimerizations reactions in general rely on the use of $\mathrm{Co}(\mathrm{I})$ precatalysts or the in situ generation of $\mathrm{Co}(\mathrm{I})$ catalysts from $\mathrm{Co}(\mathrm{II})$ sources by reduction in the presence of steering ligands, often by addition of less noble metals. In this paper, we report the synthesis and properties of novel stable $\mathrm{CpCo}$ (III) complexes as precatalysts and their exemplary evaluation for application in catalytic $[2+2+2]$ cycloadditions. The role of phosphite neutral ligands, as well as iodide and cyanide as anionic ligands, on the reactivity of the complexes was evaluated. A modified one-pot approach to the synthesis of $\mathrm{Cp}$ ring-functionalized $\mathrm{Cp}$ ' $\mathrm{Co}$ (III) complexes was developed. The investigations demonstrated that $\mathrm{CpCo}(\mathrm{III})$ complexes can be directly applied as catalysts in catalytic cyclotrimerizations of triynes without reducing agents as additives.
\end{abstract}

Keywords: cobalt(III) complexes; complex synthesis; [2+2+2] cycloaddition reactions; cyclopentadienyl ligand; olefins; phosphites

\section{Introduction}

The chemistry of $\mathrm{CpCo}(\mathrm{III})$ and $\mathrm{Cp}^{*} \mathrm{Co}(\mathrm{III})$ complexes $(\mathrm{Cp}=$ cyclopentadienyl, $\mathrm{Cp}^{*}=$ pentamethylcyclopentadienyl) have gained a lot of attention during the recent decade, especially also due to their role in studying $\mathrm{C}-\mathrm{H}$ functionalization reactions with respect to their capability compared to the latter group 9 metals [1]. Therefore, the chemistry of the $\mathrm{CpCo}$ (III) fragment came into focus from the perspective of catalysis and related organometallic chemistry [2]. Novel applications of such complexes in transformations, such as transfer hydrogenations under aerobic conditions, have been studied only recently [3]. The compound $\mathrm{CpCo}(\mathrm{CO})_{2}$ is the suitable precursor for the synthetic entry, especially due to the easy availability of air-stable $\mathrm{CpCo}$ (III) complexes like $\mathrm{CpCoI}_{2}(\mathrm{CO})(\mathbf{1})$ by simple reaction with elemental iodine [4]. Since the early stages of half-sandwich complex chemistry the compound $\mathrm{CpCoI}\left(\mathrm{PPh}_{3}\right)$ was synthesized and further derivatization reactions were investigated [5], including the possible synthesis of cobaltacyclopentadienes by reaction with dilithiated butadienes [6]. Cationic $\mathrm{CpCo}$ (III) complexes, generated by abstraction of the two iodides from $\mathrm{CpCoI}_{2}\left(\mathrm{PPh}_{3}\right)$, have found to undergo orthometalation reaction with trans-azobenzene [7]. However, none of such complexes have been systematically tested as catalyst in cyclotrimerizations, neither as phosphine nor phosphite complexes [8-15]. While phosphines proved to be detrimental to the catalytic activity of the CpCo fragment, phosphites turned out to dissociate significantly easier, however, still providing sufficient stabilization of the precatalyst [16]. The presented study is concerned with the synthesis of $\mathrm{CpCo}(\mathrm{III})(\mathrm{L})(\mathrm{X})_{2}$ complexes and the study of their reactivity as precatalysts in $[2+2+2]$ cycloaddition reactions of triynes and diynes/nitriles.

\section{Results and Discussion \\ 2.1. Synthesis of $\mathrm{CpCo(III)}$ Complexes}

The ligand exchange of the $\mathrm{CO}$ ligand in $\mathrm{CpCoI}_{2}(\mathrm{CO})(\mathbf{1})$ for phosphite ligands is a very smooth process, which we were able to demonstrate by the ligand exchange reac- 
tions shown in Scheme 1. A series of phosphites was investigated, including those with electron-donating (e.g., $\left.\mathrm{P}(\mathrm{O} \text { - } \mathrm{Pr})_{3}, \mathrm{P}(\mathrm{OCy})_{3}\right)$ and electron-withdrawing (e.g., $\mathrm{P}\left(\mathrm{OC}_{6} \mathrm{~F}_{5}\right)_{3}$, $\mathrm{P}\left(\mathrm{OCH}\left(\mathrm{CF}_{3}\right)_{2}\right)$ groups. Such substitutions on $\mathbf{1}$ have been published by Brill and Tulip et al. or Pauson et al. using $\mathrm{P}(\mathrm{OMe})_{3}$ as the structurally simplest phosphite $[17,18]$. In our case, the exchange reactions occurred in general at room temperature and very good to excellent yields for 2-4, 6 and 7 were obtained. An exception was observed for the sterically highly demanding tri(2,4-di-tert-butylphenyl)phosphite, which reacted very sluggishly and did not allow to isolate pure complex 5 in any useful amount. Additionally, the attempted repeated synthesis with $\mathrm{P}(\mathrm{OPh})_{3}$ as ligand failed, which we currently cannot substantiate with an clear explanation. The products of the successful substitutions were simply isolated by filtration and washing. These complexes are air-stable compounds, soluble in polar organic solvents. It is interesting to note that the ${ }^{31} \mathrm{P} N \mathrm{NM}$ shifts in complexes 2 (117.4 ppm) and 3 (118.0 ppm) are shifted around $50 \mathrm{ppm}$ to higher field compared to the $\mathrm{CpCo}(\mathrm{CO})$ (phosphite) complexes and shifted still roughly $30 \mathrm{ppm}$ to higher field in the case of $\mathrm{CpCo}$ (olefin)(phosphite) complexes [19]. Both classes of neutral ligands with low-lying $\pi^{*}$ orbitals inherit ligand back-bonding capabilities for electron density from the cobalt center, thus allowing larger electron-density donation from the phosphites to the metal center compared to the iodide atoms in $\mathbf{2}$ and 3. This trend was also observed for complex 4 containing the fluorinated phosphite $\mathrm{P}\left[\mathrm{OCH}\left(\mathrm{CF}_{3}\right)_{2}\right]_{3}$.

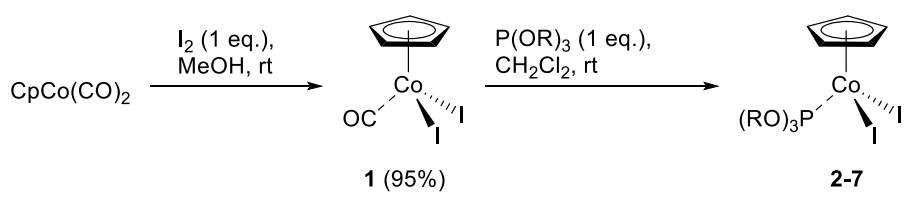

Yields for the 2. step:

$\mathrm{CpCol}_{2}\left[\mathrm{P}(\mathrm{O} i-\mathrm{Pr})_{3}\right](2): 99 \%$ yield $\quad \mathrm{CpCol}_{2}\left\{\mathrm{P}\left[\mathrm{O}-2,4-(t-\mathrm{Bu})_{2} \mathrm{C}_{6} \mathrm{H}_{3}\right]_{3}\right\}(5)$ : no pure isolation possible $\mathrm{CpCol}_{2}\left[\mathrm{P}(\mathrm{OCy})_{3}\right](3): 84 \%$ yield $\quad \mathrm{CpCol}_{2}\left[\mathrm{P}\left(\mathrm{OC}_{6} \mathrm{~F}_{5}\right)_{3}\right](6): 81 \%$

$\mathrm{CpCol}_{2}\left\{\mathrm{P}\left[\mathrm{OCH}\left(\mathrm{CF}_{3}\right)_{2}\right]_{3}\right\}(4): 90 \% \quad \mathrm{CpCol}_{2}\left[\mathrm{P}\left(\mathrm{O}-4-\mathrm{CF}_{4}-\mathrm{C}_{6} \mathrm{H}_{4}\right)_{3}\right](7): 85 \%$

Scheme 1. Synthesis of phosphite complexes from $\mathrm{CpCoI}_{2}(\mathrm{CO})(\mathbf{1})$ and different phosphites.

For further comparison, we also synthesized complexes containing cyano groups to elucidate the influence of this pseudo halide on complex reactivity. It is known that cyanogen iodide, ICN, reacts smoothly with $\mathrm{CpCo}(\mathrm{CO})_{2}$, although the resulting compound has never been investigated further for catalytic purposes [20]. Again, substitution of the second $\mathrm{CO}$ ligand for a phosphite occurred smoothly for complex $\mathbf{8}$ as was demonstrated with $\mathrm{P}(\mathrm{O} i-\mathrm{Pr})_{3}$. In addition, we realized the exchange of both iodide atoms in compound $\mathbf{2}$ in the presence of alkali metal cyanide, yielding complex $\mathbf{1 0}$ [21,22]. The synthesis results are displayed in Scheme 2. According to the cited reference for the synthesis [21], replacement of the iodides for cyanide groups in the presence of the CO ligand like in complex $\mathbf{1}$ is not possible, because it would lead to the formation of undesired reaction products. Therefore, the presented sequence of substitution (first $\mathrm{CO}$ exchange for the phosphite ligand, then substitution of the iodide for the cyanide) is mandatory.

Due to the stability of the Co(III) diiodides, we exemplarily investigated this approach for the synthesis of a functionalized $\mathrm{Cp}^{\prime} \mathrm{CoI}_{2}(\mathrm{CO})$ complexes from the corresponding substituted cyclopentadiene and $\mathrm{Co}_{2}(\mathrm{CO})_{8}$, while avoiding the work-up of intermediates like 12 or 13 (Scheme 3). The reaction started out from NaCp by acetyoxylation with dimethylcarbonate to give 12. Cobaltation with in situ generated $\left[\mathrm{ICo}(\mathrm{CO})_{4}\right]$ resulted in the formation of the cobalt dicarbonyl complex 13, which was directly reacted with iodine without isolation to furnish compound $\mathbf{1 4}$ as pure complex with $14 \%$ yield over three steps. Subsequent ligand exchange with triisopropyl phosphite furnished complex $\mathbf{1 5}$ with excellent yield. Attempts to synthesize the related Cp-acetylated complex led to the formation of the expected product, however, all attempts of isolating the pure $\mathrm{Co}$ (III)complexes after the methods reported for $\mathbf{1 4}$ and $\mathbf{1 5}$ were not met with success. 


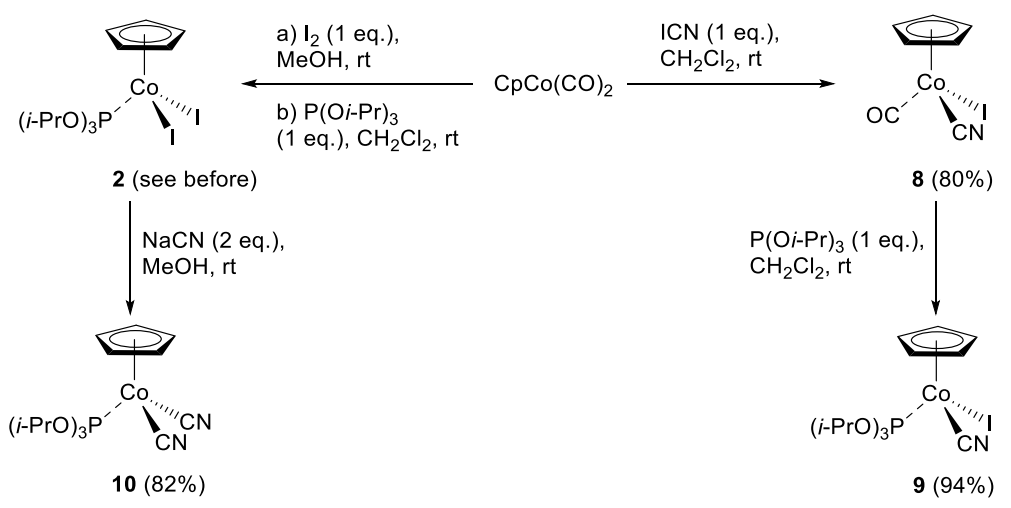

Scheme 2. Synthesis of $\mathrm{CpCo}(\mathrm{III})\left(\right.$ phosphite) complexes from $\mathrm{CpCo}(\mathrm{CO})_{2}$, iodine or ICN and triisopropyl phosphite.

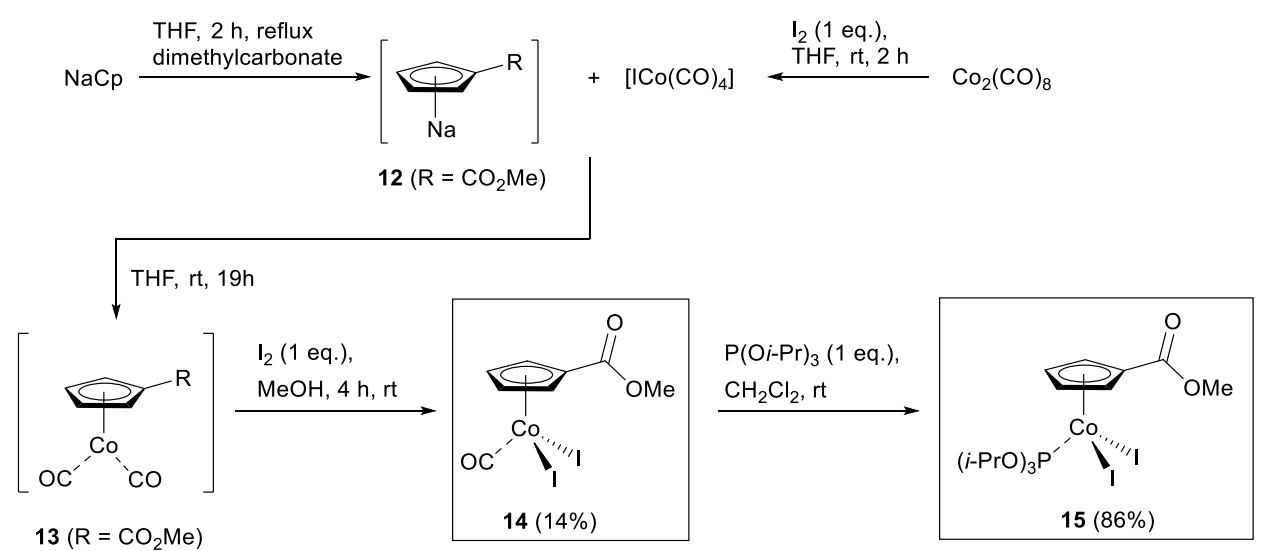

Scheme 3. Synthesis of functionalized Cp'Co diiodides 14 and 15 in an one-pot approach.

\subsection{Screening on Catalytic Activity of the CpCo(III) Precatalysts}

As mentioned above, we surveyed possible reducing agents in the required reduction to catalytically active $\mathrm{CpCo}(\mathrm{I})$ species. The conventional reduction protocol using zinc powder and zinc(II) iodide as additive did not work well [22]. After one hour of pretreatment of complexes 2 and 3 either in THF $\left(50{ }^{\circ} \mathrm{C}\right)$ or toluene $\left(100{ }^{\circ} \mathrm{C}\right)$ with 2 eq. of $\mathrm{Zn}$ powder and $\mathrm{ZnI}_{2}$ each, the resulting catalyst furnished the pyridine product from 1,6-heptadiyne and benzonitrile in the test reaction with either $11 \%$ (in THF) or $6 \%$ yield (in toluene) at maximum.

We turned our attention to cyclizations with the standard testing triyne $\mathbf{1 6}$ and were quite surprised to see that in the initial experiment with $\mathrm{CpCoI}_{2}(\mathrm{CO})$ without any reducing agent, the cyclization product 16cycl was obtained with $38 \%$ yield after $19 \mathrm{~h}$ at reaction temperatures as low as $75^{\circ} \mathrm{C}$ (Table 1 , entry 1 ). In comparison, with $\mathrm{CpCo}(\mathrm{CO})_{2}$ no reaction was observed under these conditions (Table 1, entry 14). Reactivity screening of complexes $\mathbf{2}$ and 3 gave yields as high as $55 \%$ with precatalyst 2 (Table 1, entry 2), while clearly the nature of the phosphite ligand does play a role, as with precatalyst 3 containing $\mathrm{P}(\mathrm{OCy})_{3}$ a significantly lower yield of only $22 \%$ was observed (Table 1 , entry 3 ). Investigation of other ligands containing partially or completely fluorinated groups and thus being less electron-rich like in complexes 4,6 and 7 gave inferior results ranging from $8 \%$ to $27 \%$ (Table 1, entries 4-6). Finally, we also investigated the complexes 8 and 9 with heteroleptic (I/CN) anionic groups beside the $\mathrm{Cp}$ and $\mathrm{CO}$ or phosphite ligand. They did not show any catalytic activity at either 75 or $100{ }^{\circ} \mathrm{C}$ (Table 1, entries 7-9). The biscyanide complex 10, however, showed remarkably different reactivity. While no reactivity was observed at $75{ }^{\circ} \mathrm{C}$, raising the reaction temperature to $105^{\circ} \mathrm{C}$ allowed isolation of the 
product 16cycl with $84 \%$ yield (Table 1 , entries 10 and 11). The difference of $30{ }^{\circ} \mathrm{C}$ in reaction temperature clearly covers the range leading to the catalyst activation, while at $75^{\circ} \mathrm{C}$ the complex is completely stable and unreactive. Finally, the ester-substituted analogs 14 and 15 showed both identical results for the cyclization, although less yield of $\mathbf{1 6 c y c l}$ compared to the unsubstituted precatalyst 2 (Table 1, entries 2, 12 and 13 for comparison). Clearly, the substitution did not change the reactivity profile significantly. Interestingly, the yield obtained in this transformation for catalyst 2 is in the range of the most reactive $\mathrm{CpCo}$ (olefin)(phosphite) precatalysts for the reaction at $75^{\circ} \mathrm{C}[19]$.

Table 1. Screening of cyclization reactions with substrate 16 using different complexes 1-4, 6-10 and 14 and 15 as well as $\mathrm{CpCo}(\mathrm{CO})_{2}$ for comparison.

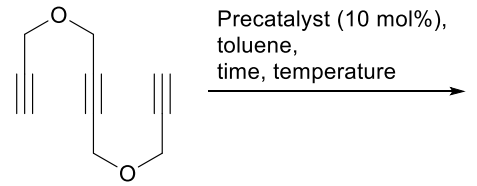

16

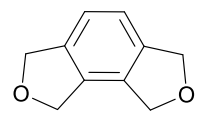

$16 \mathrm{cycl}$

\begin{tabular}{ccccc}
\hline$\#$ & Precatalyst & Time (h) & Temperature $\left({ }^{\circ} \mathbf{C}\right)$ & Yield $\mathbf{( \% )} \mathbf{a}^{\mathbf{a}}$ \\
\hline Entry 1 & $\mathbf{1}$ & 19 & 75 & 38 \\
Entry 2 & $\mathbf{2}$ & 22 & 75 & 55 \\
Entry 3 & $\mathbf{3}$ & 20 & 75 & 22 \\
Entry 4 & $\mathbf{4}$ & 21 & 75 & 27 \\
Entry 5 & $\mathbf{6}$ & 21 & 75 & 25 \\
Entry 6 & 7 & 21 & 75 & 8 \\
Entry 7 & $\mathbf{8}$ & 14 & 75 & $-\mathrm{b}, \mathrm{c}$ \\
Entry 8 & $\mathbf{9}$ & 21 & 75 & $-\mathrm{b}, \mathrm{c}$ \\
Entry 9 & $\mathbf{9}$ & 23 & 100 & $-\mathrm{b}, \mathrm{c}$ \\
Entry 10 & $\mathbf{1 0}$ & 21 & 75 & $-\mathrm{b}, \mathrm{d}$ \\
Entry 11 & $\mathbf{1 0}$ & 21 & 105 & 84 \\
Entry 12 & $\mathbf{1 4}$ & 16 & 75 & 48 \\
Entry 13 & $\mathbf{1 5}$ & 20 & 75 & 44 \\
Entry 14 & $\mathrm{CpCo}(\mathrm{CO})_{2}$ & 19 & 75 & $-\mathrm{b}, \mathrm{e}$
\end{tabular}

${ }^{a}$ Isolated yields. ${ }^{b}$ No reaction at all was observed. ${ }^{c} 16$ recovered (between 80\% and 88\%). ${ }^{\mathrm{d}} \mathbf{1 6}$ and 10 recovered.

e 16 was fully recovered.

We further exemplarily investigated modified reaction conditions, particularly to raise the conversion of the used testing triyne 16. The complex $\mathrm{CpCo}\left[\mathrm{P}(\mathrm{O} i-\mathrm{Pr})_{3}\right]_{2}(2)$ was applied as standard catalyst in these investigations (Table 2). Application of microwave reaction conditions at $100{ }^{\circ} \mathrm{C}$ shortened the reaction time but led to lower yield for $16 \mathrm{cycl}$ even after $12 \mathrm{~h}$ reaction time compared to the reaction at $75{ }^{\circ} \mathrm{C}(25$ and $41 \%$ vs. $55 \%$, Table 2 , entries 1 and 2). Increasing the catalyst loading to $20 \mathrm{~mol} \%$ gave a yield of $56 \%$ (Table 2, entry 3 ) under microwave conditions. We also investigated the utilization of silver(I) acetate as iodide abstracting agent, often used for catalytic reactions with $\mathrm{Cp}^{*} \mathrm{Co}(\mathrm{CO}) \mathrm{I}_{2}$ [23]. In the first experiment, utilizing $20 \mathrm{~mol} \%$ of silver(I) acetate the cyclization product 16cycl was formed with $20 \%$ yield and the starting material was mostly reisolated (Table 2, entry 4). Repeating the experiment with only $10 \mathrm{~mol} \%$ of silver(I) acetate under otherwise identical conditions gave with only $5 \%$ yield of $\mathbf{1 6}$ an even significantly lower yield (Table 2, entry 5). An experiment in which additional $10 \mathrm{~mol} \%$ catalyst 2 were added after $12 \mathrm{~h}$ reaction time and the reaction run for additional $12 \mathrm{~h}$ was conducted but did not lead to an increase in yield (Table 2, entry 6). However, beside isolation of $43 \%$ of $16 \mathrm{cycl}$ only $15 \%$ of 16 were recovered, giving a strong hint towards the occurrence of side reactions. Finally, addition of elemental zinc as reductant led to $53 \%$ product yield after $48 \mathrm{~h}$ at $75{ }^{\circ} \mathrm{C}$, beside $8 \%$ of reisolated 16 (Table 2, entry 7). The missing amount of triyne not found in product or substrate again points towards side reaction with these catalysts. 
Table 2. Screening of reaction conditions and additives for the cyclization of $\mathbf{1 6}$ using complex 2.
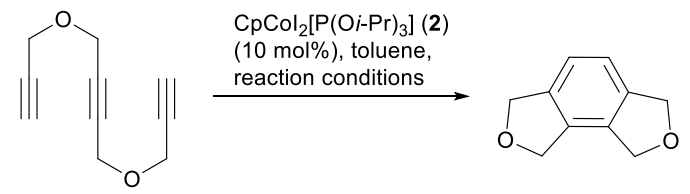

16

$16 \mathrm{cycl}$

\begin{tabular}{ccccc}
\hline$\#$ & $\mathbf{2}(\mathbf{m o l} \mathbf{\%})$ & Time $\mathbf{( h )}$ & Temperature $^{\left({ }^{\circ} \mathbf{C}\right)}$ & Yield $\left.^{(\%)}\right)^{\mathbf{a}}$ \\
\hline Entry 1 & 10 & 4 & $100(\mathrm{MW})^{\mathrm{b}}$ & 25 \\
Entry 2 & 10 & 12 & $100(\mathrm{MW})$ & 41 \\
Entry 3 & 20 & 4 & $100(\mathrm{MW})$ & 56 \\
Entry 4 & 10 & 18 & 75 & $20(58){ }^{\mathrm{c}, \mathrm{f}}$ \\
Entry 5 & 10 & 18 & 75 & $5(74)^{\mathrm{d}, \mathrm{f}}$ \\
Entry 6 & $20(2 \times 10)$ & $24(2 \times 12 \mathrm{~h})$ & 100 & $43(15)^{\mathrm{f}}$ \\
Entry 7 & 10 & 48 & 75 & $53(8)^{\mathrm{e}, \mathrm{f}}$ \\
\hline
\end{tabular}

a Isolated yields. ${ }^{\mathrm{b}} \mathrm{MW}=$ microwave. ${ }^{\mathrm{c}}$ Additive: AgOAc $(20 \mathrm{~mol} \%) .{ }^{\mathrm{d}}$ Additive: $\mathrm{AgOAc}(10 \mathrm{~mol} \%) .{ }^{\mathrm{e}}$ Additive: zinc powder $(10 \mathrm{~mol} \%) .{ }^{\mathrm{f}}$ The amount of reisolated $\mathbf{1 6}$ is given in parentheses.

We extended our investigations to the cyclization of terminal substituted triynes, which are usually less reactive than the terminally unsubstituted triynes. The results for the substrate triynes $\mathbf{1 7}$ and $\mathbf{1 8}$ are presented in Scheme 4 . In both cases using precatalyst $\mathbf{2 ,}$ the reaction at $75^{\circ} \mathrm{C}$ did not give any progress and only unreacted triynes were observed. Due to this reason, the reaction temperature of the experiments were raised to $100{ }^{\circ} \mathrm{C}$ for additional time finally yielded cyclization products $17 \mathrm{cycl}$ and $\mathbf{1 8 c y c l}$, albeit in rather low yields. Due to the lower reactivity of the terminal substituted triynes and required higher temperatures for reaction with $\mathrm{CpCo}$ complexes, we investigated the reactions under microwave conditions at $140{ }^{\circ} \mathrm{C}$. For triyne 17 , very good $75 \%$ yield of $17 \mathrm{cycl}$ was obtained and isolated. However, triyne $\mathbf{1 8}$ gave only minor or no cyclization product 18cycl at all. Interestingly, while under Cond. A most of triyne $\mathbf{1 8}$ was recovered, at the higher reaction temperatures of Cond. B only $27 \%$ of starting material was reisolated. A possible reason would be consummation of $\mathbf{1 8}$ by a side reaction like polymerization, as no defined further reaction products were isolated.
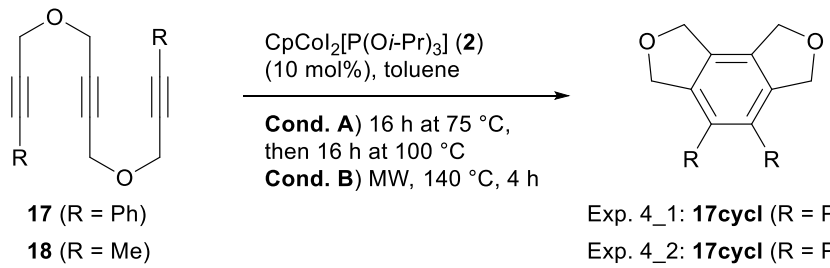

Exp. 4_1: 17cycl $(\mathrm{R}=\mathrm{Ph}): 24 \%($ Cond. A)
Exp. 4_2: $\mathbf{1 7} \operatorname{cycl}(\mathrm{R}=\mathrm{Ph}): 75 \%($ Cond. $\mathrm{B})$
Exp. 4_3: $\mathbf{1 8 c y c l}(\mathrm{R}=\mathrm{Me}): 5 \%, 76 \% \mathbf{2 1}$ reisolated $($ Cond. A)
Exp. 4_4: 18cycl $(\mathrm{R}=\mathrm{Me}): 0 \%, 27 \% \mathbf{2 1}$ reisolated (Cond. B)

Scheme 4. Conditions for cyclizations with internal triynes 17 and 18 using precatalyst 2.

For cyclizations with CpCo complexes, the cobalt oxidation state of +1 is the common feature of the catalytically active species entering the catalytic cycle. We therefore further investigated additional methods to activate the catalyst system by facilitating intramolecular reduction from a $\mathrm{CpCo}(\mathrm{III})$ species to a $\mathrm{CpCo}(\mathrm{I})$ species by reductive elimination. For late transition metals, reductive elimination of carbon-based substituents from the metal center is a very common and important process, e.g., in C-C coupling reactions, and it has been investigated theoretically and experimentally for the reductive elimination of ethane from $\mathrm{L}_{3} \mathrm{CoMe}_{2} \mathrm{I}\left(\mathrm{L}=\mathrm{PMe}_{3}\right)$ complexes [24]. The complex $\mathrm{CpCo}(\mathrm{Me})_{2}\left(\mathrm{PPh}_{3}\right)$ has been synthesized by the reaction of $\mathrm{CpCoI}_{2}\left(\mathrm{PPh}_{3}\right)$ with $\mathrm{MeMgBr}$ and did react with alkynes afterwards under reduction and formation of cobaltacyclopentadienes [25,26]. Therefore, we attempted alkylation of the diiodide complex 2 by reaction with the Grignard reagent $\mathrm{MeMgBr}$ to produce the dimethylated analogue (2-Me) and set out to investigate 
its catalytic performance (Scheme 5). ${ }^{1} \mathrm{H}$ NMR analysis confirmed the alkylation success of this reaction due to the unique shift of the resonance for the methyl group to $0 \mathrm{ppm}$, however, only partial alkylation was recognizable. Reaction control by ${ }^{31} \mathrm{P}$ NMR spectroscopy confirmed disappearance of $\mathbf{2}$ as well and emergence of two new resonances at 160 and $172 \mathrm{ppm}$. Utilization of $10 \mathrm{~mol} \%$ (estimated for assumed complete conversion of 2 ) for the catalytic cyclization of $\mathbf{1 6}$ furnished the expected product $\mathbf{1 6 c y c l}$, albeit with slightly lower yield than before, not providing any significant advantage. A comparable investigation of 1,6-heptadiyne and benzonitrile as standard system for pyridine formation by co-cyclo-trimerization gave mediocre $30 \%$ yield of pyridine 19 , which is significantly lower compared to $\mathrm{CpCo}$ (olefin)(phosphite) precatalysts under identical conditions [19]. Replication of the experiment by treating partially fluorinated complex 4 with $\mathrm{MeMgBr}$ and direct subsequent reaction of the reaction product with triyne $\mathbf{1 6}$ gave cyclization product 16 cycl with $31 \%$ yield ( $44 \% 16$ recovered).

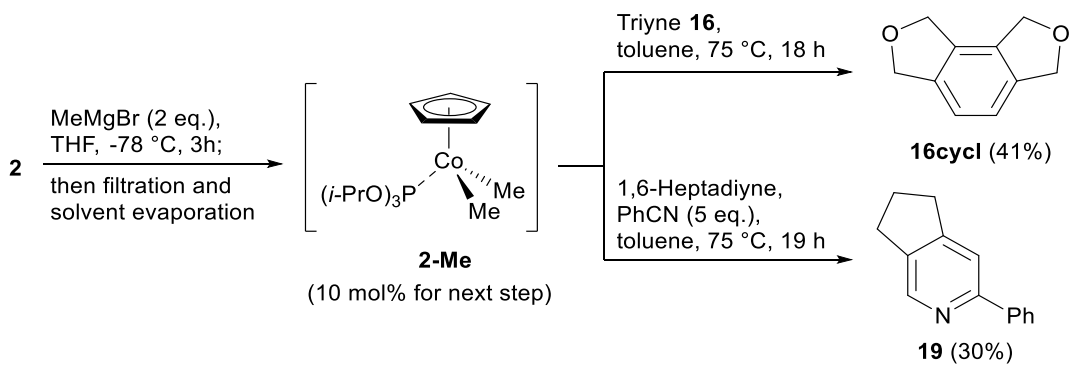

Scheme 5. Investigated cyclizations with methylated complex 2-Me.

We repeated this procedure with the complex $\mathbf{9}$, containing iodide and cyanide as anionic groups (Scheme 6). Reaction with one equivalent of the Grignard reagent led to conversion of 9 , being confirmed by ${ }^{1} \mathrm{H}$ and ${ }^{31} \mathrm{P}$ NMR spectroscopy reaction control, in the latter case by a shift from $126.7 \mathrm{ppm}$ (9) to $142.4 \mathrm{ppm}$ (9-Me). Subsequent direct use of the generated species 9-Me as catalyst gave surprising results compared to Scheme 5 . In the case of pyridine (19) synthesis, the yields are slightly lower, independent from the reaction temperature and no difference appeared for 9-Me at both temperatures (compare Schemes 5 and 6, below). The picture is different for the cyclization of 16, where the yield was basically doubled at $100{ }^{\circ} \mathrm{C}$ reaction temperature and are still significantly higher at $75^{\circ} \mathrm{C}$ compared to 2-Me (Scheme 6, top). This observation is particularly interesting, as complex 9 did not show any reactivity in the cyclization of 16 before (Table 1 , entries 8, 9). Replacement of the iodide for the methyl group clearly increases the reactivity in the presence of cyanide as second anionic ligand, including reactivity already observed at $75^{\circ} \mathrm{C}$, when the biscyanide complex 10 was completely inactive (see Table 1, entry 10). A possible reason for this is the stronger bonding of the nitrile group vs. the methyl group, requiring more energy to induce the formation of a reactive species for the catalytic process.

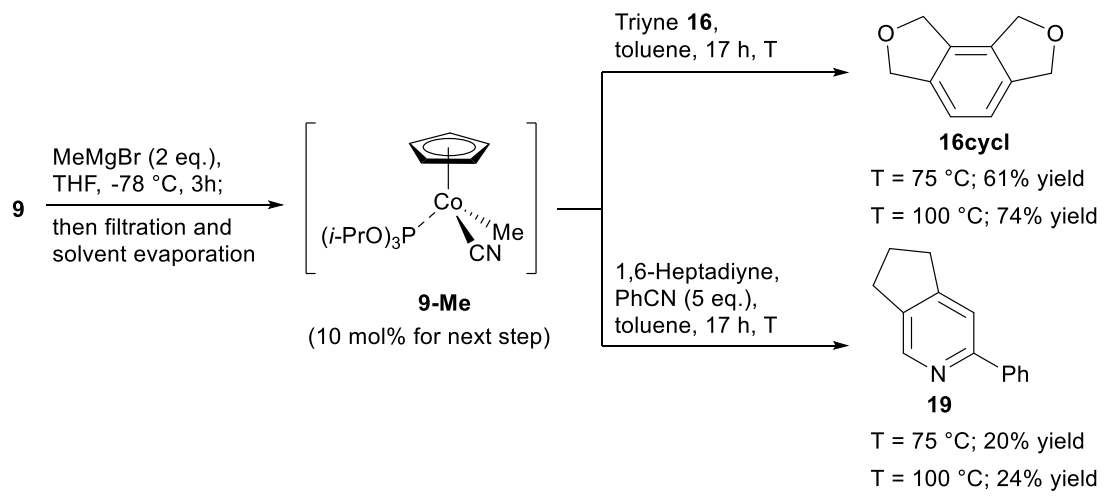

Scheme 6. Investigated cyclizations with methylated complex 9-Me. 
We assumed that the catalytic activity might arise from preceding reduction of the $\mathrm{CpCo}(\mathrm{III})$ complex to a $\mathrm{CpCo}(\mathrm{I})$ complex. There is evidence for this assumption for $\mathrm{CpCo}(\mathrm{III})\left(\mathrm{PPh}_{3}\right)$-dialkyl complexes like $\mathrm{CpCo}(\mathrm{Me})_{2}\left(\mathrm{PPh}_{3}\right)$, who gave cobaltacyclopentadienes upon reaction with alkynes under thermal conditions, implying reductive elimination of the alkyl groups [25]. However, the $\mathrm{PPh}_{3}$ ligand is detrimental for the catalytic activity of the complexes and less comparable to phosphites as ligand in this setting. Experiments with 2 under addition of elemental zinc did basically show no difference compared to catalysis with 2 without additive (compare entries Tables 1 and 2). The simplest process would thus be reductive elimination of the anionic groups. While this can be imagined with complex 9-Me (reductive elimination of $\mathrm{MeCN}$ ), the elimination from diiodide complex $\mathbf{2}$ or dicyanide complex $\mathbf{1 0}$ are significantly less likely. We investigated this possibility for the latter by scavenging experiments, as the complexes are heated in the presence of dimethyl fumarate, leading in the case of successful reductive elimination processes to $\mathrm{CpCo}\left[\mathrm{P}(\mathrm{O} i-\mathrm{Pr})_{3}\right]($ dimethyl fumarate) (20) and the corresponding elimination products. However, the experiments showed neither in the NMR experiment nor on preparative scale that reductive elimination occurred from the $\mathrm{CpCo}$ (III) complexes (Scheme 7).
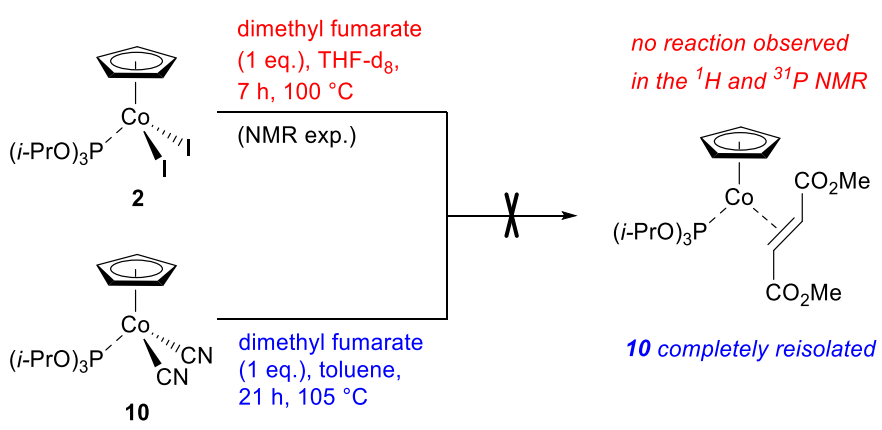

10 completely reisolated

Scheme 7. Attempted scavenging experiments towards reductive elimination from precatalysts 2 and 10.

We have reacted complex $\mathbf{2}$ and triyne $\mathbf{1 6}$ in a 1:1 ratio to prove if complex $\mathbf{2}$ is converted during the reaction (Scheme 8 ). The ${ }^{1} \mathrm{H}$ and ${ }^{31} \mathrm{P}$ NMR spectra before and after heating to $100{ }^{\circ} \mathrm{C}$ showed, that complete conversion of 16 to $16 \mathrm{cycl}$ has occurred. The ${ }^{31} \mathrm{P}$ NMR shows a single signal at $120 \mathrm{ppm}$ before and after the reaction, corresponding to an unchanged coordination environment for the triisopropyl phosphite. However, from the spectra one cannot deduce an unchanged complex 2 after the reaction because of overlaps of signals in the ${ }^{1} \mathrm{H}$ NMR spectra and shifted or disappeared signals in the region of the $\mathrm{Cp}$ group. On the other hand, the spectra did not contain significant traces of byproducts or decomposition products as well and the cyclization appeared to be a rather clean process.

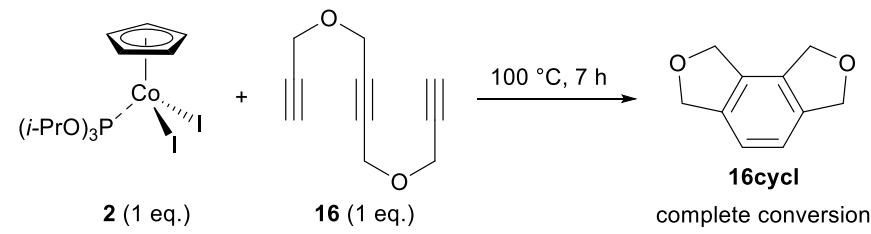

Scheme 8. Stoichiometric transformation of precatalyst $\mathbf{2}$ with triyne $\mathbf{1 6}$ for NMR investigation (in Supplementary Materials).

Finally, we investigated the reactivity of cationic $\mathrm{CpCo}(\mathrm{III})$ complexes in these cyclizations for comparison and to see, if they provide any cyclization activity by itself (Scheme 9). For this purpose, two eq. silver(I) tetrafluoroborate were added to the reaction mixture and a precipitate was formed. Under thermal as well as microwave conditions at higher temperatures cyclization products $16 \mathrm{cycl}$ and $\mathbf{1 7 c y c l}$ were formed, however with 
significantly lower yields compared to the reactions without $\mathrm{AgBF}_{4}$ (compare Table 1 and Scheme 4). This result points towards a possible different reaction mechanism initiated by the cationic $\mathrm{CpCo}$ (III) complex compared to the commonly accepted mechanisms for $\mathrm{CpCo}$ complexes [27].

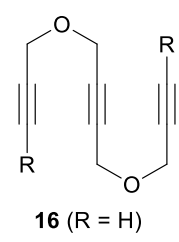

$17(\mathrm{R}=\mathrm{Ph})$
$\mathrm{CpCol}_{2}\left[\mathrm{P}(\mathrm{O} i-\mathrm{Pr})_{3}\right](2)$

$(10 \mathrm{~mol} \%), \mathrm{AgBF}_{4}$

(20 mol\%), toluene

Cond. A) $21 \mathrm{~h}$ at $75^{\circ} \mathrm{C}$ Cond. B) MW, $140^{\circ} \mathrm{C}, 4 \mathrm{~h}$

$+36 \% 17$ reisolated

Scheme 9. Cyclizations of $\mathbf{1 6}$ and $\mathbf{1 7}$ using precatalyst $\mathbf{2}$ and $\mathrm{AgBF}_{4}$ as additive.

Cationic $\mathrm{CpCo}(\mathrm{III})$ complexes can also be synthesized from the dicyano complex $\mathbf{1 0}$ by treatment with a strong alkylation reagent $[18,21]$. Reaction of $\mathbf{1 0}$ with trimethyloxonium tetrafluoroborate furnished the dicationic salt 21 with excellent isolated yield (Scheme 10).

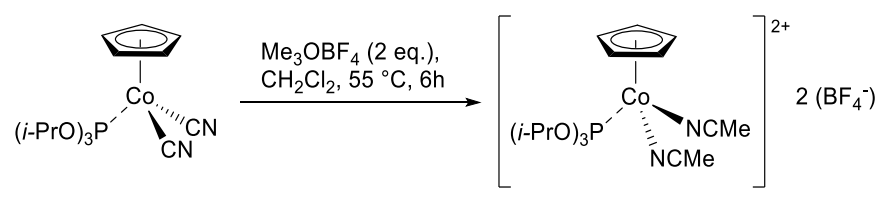

10

$21(94 \%)$

Scheme 10. Transformation of complex 10 to the dicationic complex 21.

The reactivity screening with complex $\mathbf{2 1}$ was again undertaken for triynes $\mathbf{1 6}$ and $\mathbf{1 7}$ (Scheme 11).

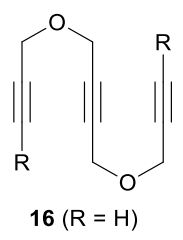

$17(\mathrm{R}=\mathrm{Ph})$

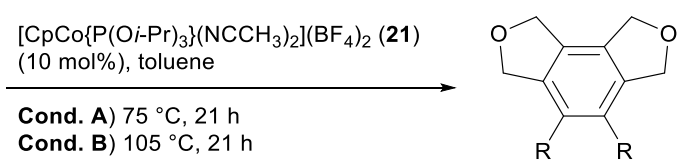

16 cycl $(\mathrm{R}=\mathrm{H}): 0 \%$ (Cond. $A)+92 \% 16$ reisolated

16 cycl $(R=H): 57 \%$ (Cond. B) $+36 \% 16$ reisolated

17 cycl $(\mathrm{R}=\mathrm{Ph}$ ): $0 \%$ (Cond. $\mathrm{A})+91 \% 17$ reisolated

$17 \mathrm{cycl}(\mathrm{R}=\mathrm{Ph}): 5 \%$ (Cond. $\mathrm{B})+89 \% 17$ reisolated

Scheme 11. Attempted cyclizations of $\mathbf{1 6}$ and $\mathbf{1 7}$ using precatalyst 21.

The cationic precatalyst 21 did not give any reactivity at $75^{\circ} \mathrm{C}$ with either triyne $\mathbf{1 6}$ or 17 and starting material as well as catalyst were recovered. At $105{ }^{\circ} \mathrm{C}$ terminally unsubstituted triyne $\mathbf{1 6}$ gave $57 \%$ yield of $\mathbf{1 6 c y c l}$ and most of unreacted $\mathbf{1 6}$ was recovered, pointing towards a clean conversion without by-product formation. With triyne 17 only negligible cyclization reactivity was observed, while again most of the starting material was recovered. The reactions appeared to be quite clean because no significant amount of starting material was consumed for undesired reactions, dividing this reaction from the combination of complex $2 / \mathrm{AgBF}_{4}$ (Scheme 9). Overall, the isolated complex 21 is less reactive compared to the in situ generated cationic complex, as demonstrated by the reactivity towards 16 at $75{ }^{\circ} \mathrm{C}$ reaction temperature. The complex shows no significant reactivity for the cyclization of internal triyne 17 , which is more difficult to transform compared to triyne 16. Future investigations will be directed to the elucidation of the reactivity of such cationic $\mathrm{CPCo}(\mathrm{III})$ complexes at higher reaction temperatures and the 
general differences in the mode of action in cyclizations of such $\mathrm{CpCo}(\mathrm{III})$ precatalysts compared to the common $\mathrm{CpCo}(\mathrm{I})$ precatalysts.

\section{Experimental Section}

\subsection{Methods and Materials}

All experiments were carried out under inert gas atmosphere (argon) in flame dried Schlenk tubes or glass reaction vials. The anhydrous solvents (tetrahydrofuran, toluene, dichloromethane and $n$-hexane) were dried in a solvent purification system MD-5 from Inert (former Innovative Technology, Amesbury, MA, USA). All NMR spectra were recorded on a Bruker AV 300, AV 400, AV 500 or Fourier 300 NMR spectrometer (Rheinstetten, Germany). Elemental analysis was performed at a Perkin Elmer AAS-Analyst 300 (Co) (Hamburg, Germany), Leco Microanalysator-TruSpec CHNS (C, H) (Mönchengladbach, Germany), Radiometer Analytical SAS (Titrator) Titralab 870-TIM 870 (Br) (Villeurbanne, France) and a Perkin Elmer UV/VIS-spectrometer Lambda 2 (P) (Hamburg, Germany).

\subsection{Synthesis of Complexes}

Attention: Due to evolution of $\mathrm{CO}$ gas the reactions comprising $\mathrm{CO}$ ligand exchange need be performed in a well-ventilated fume hood!

Synthesis of $\mathrm{CpCoI}_{2}(\mathrm{CO})(\mathbf{1})$ [4]: $\mathrm{CpCo}(\mathrm{CO})_{2}(3.0 \mathrm{~g}, 16.6 \mathrm{mmol})$ was dissolved in methanol and solid iodine $(4.23 \mathrm{~g}, 16.6 \mathrm{mmol}, 1 \mathrm{eq}$.$) added in small portions, while$ evolution of $\mathrm{CO}$ gas was taking place. The color of the solution changed from red to black. The reaction mixture was stirred for additional two hours, then the methanol was removed in vacuo and the remaining black solid was dissolved in $\mathrm{CH}_{2} \mathrm{Cl}_{2}$ and filtrated over a filter frit tubing. The residual was further washed with $\mathrm{CH}_{2} \mathrm{Cl}_{2}$ and the filtrates concentrated under reduced pressure. The obtained solid product was washed three times with $\mathrm{Et}_{2} \mathrm{O}$ and allowed to dry in air (black solid, $6.42 \mathrm{~g}, 95 \%$ ). The spectroscopic data are in accordance with the literature.

General Procedure 1 (GP1), exemplified for the synthesis of $\mathrm{CpCoI}_{2}\left[\mathrm{P}(\mathrm{Oi}-\mathrm{Pr})_{3}\right]$ (2): In an adoption of a reported protocol for $\mathrm{P}(\mathrm{OMe})_{3}$ [17], $\mathrm{P}(\mathrm{O} \text { - }-\mathrm{Pr})_{3}(520 \mathrm{mg}, 2.5 \mathrm{mmol}, 1$ eq. $)$ was dissolved in $\mathrm{CH}_{2} \mathrm{Cl}_{2}(10 \mathrm{~mL})$ and added dropwise to a solution of $\mathrm{CpCoI}_{2}(\mathrm{CO})(\mathbf{1}$, $1.0 \mathrm{~g}, 2.5 \mathrm{mmol})$ in $\mathrm{CH}_{2} \mathrm{Cl}_{2}(10 \mathrm{~mL})$, during which the evolution of gas was observed. The reaction mixture was stirred for $16 \mathrm{~h}$ at $25^{\circ} \mathrm{C}$. Afterwards, the solvent was removed under reduced pressure and the residue suspended in $n$-heptane, stirred and filtrated under air. The collected black solid was dried thoroughly under reduced pressure (yield: $1.44 \mathrm{~g}, 99 \%$ ). ${ }^{1} \mathrm{H}$ NMR $\left(300 \mathrm{MHz}, \mathrm{CDCl}_{3}\right): \delta=5.20(\mathrm{~s}, 5 \mathrm{H}), 4.82(\mathrm{ht}, J=6.0 \mathrm{~Hz}, 3 \mathrm{H}), 1.37(\mathrm{~d}, J=6.0 \mathrm{~Hz}$, $18 \mathrm{H})$ ppm. ${ }^{13} \mathrm{C}$ NMR $\left(75 \mathrm{MHz}, \mathrm{CDCl}_{3}\right): \delta=87.7(\mathrm{~d}, J=3.7 \mathrm{~Hz}), 73.7(\mathrm{~d}, J=9.3 \mathrm{~Hz}), 23.9$ $(\mathrm{d}, J=3.7 \mathrm{~Hz})$ ppm. ${ }^{31} \mathrm{P}$ NMR $\left(122 \mathrm{MHz}, \mathrm{CDCl}_{3}\right): \delta=117.4$ ppm. IR: $\gamma_{\max }=3111,2974$, $2929,1417,1367,1172,1101,948,879,819,746,707,542 \mathrm{~cm}^{-1}$. Elemental analysis for $\mathrm{C}_{14} \mathrm{H}_{26} \mathrm{CoI}_{2} \mathrm{O}_{3} \mathrm{P}(\mathrm{M}=586.07 \mathrm{~g} / \mathrm{mole})$ : calc. C 28.69, $\mathrm{H}$ 4.47, Co 10.06, I 43.31, P 5.28; found C 28.53, H 4.04, Co 8.84, I 44.19, P 5.27.

Synthesis of $\mathrm{CpCoI}_{2}\left[\mathrm{P}(\mathrm{OCy})_{3}\right]$ (3): Following the GP1, $\mathrm{P}(\mathrm{OCy})_{3}(810 \mathrm{mg}, 2.5 \mathrm{mmol}$, 1 eq.) was dissolved in $\mathrm{CH}_{2} \mathrm{Cl}_{2}(10 \mathrm{~mL})$ and added dropwise to a solution of $\mathrm{CpCoI}_{2}(\mathrm{CO})(\mathbf{1}$, $1.0 \mathrm{~g}, 2.5 \mathrm{mmol})$ in $\mathrm{CH}_{2} \mathrm{Cl}_{2}(10 \mathrm{~mL})$, during which the evolution of gas was observed. The reaction mixture was also stirred for $16 \mathrm{~h}$ at $25^{\circ} \mathrm{C}$. Afterwards, the solvent was evaporated, and the residue suspended in $n$-heptane, stirred for a short period of time and filtrated under air. The isolated blackish solid was dried thoroughly under reduced pressure (yield: $1.47 \mathrm{~g}, 84 \%) .{ }^{1} \mathrm{H}$ NMR $(300 \mathrm{MHz}, \mathrm{CDCl} 3): \delta=5.20(\mathrm{~s}, 5 \mathrm{H}), 4.65-4.42(\mathrm{~m}, 3 \mathrm{H}), 2.13-1.21(\mathrm{~m}$, $30 \mathrm{H})$ ppm. ${ }^{13} \mathrm{C}$ NMR $(75 \mathrm{MHz}, \mathrm{CDCl} 3): \delta=87.7(\mathrm{~d}, J=3.7 \mathrm{~Hz}), 78.1(\mathrm{~d}, J=9.3 \mathrm{~Hz}), 33.5(\mathrm{~d}$, $J=3.3 \mathrm{~Hz}), 25.4,23.7 \mathrm{ppm} .{ }^{31} \mathrm{P}$ NMR $(122 \mathrm{MHz}, \mathrm{CDCl} 3): \delta=118.0 \mathrm{ppm}$. IR: $v_{\max }=3106$, 2930, 2855, 1447, 1369, 1260, 965, 860, 820, 762, 630, 561, $515 \mathrm{~cm}^{-1}$. Elemental analysis for $\mathrm{C}_{23} \mathrm{H}_{38} \mathrm{CoI}_{2} \mathrm{O}_{3} \mathrm{P}(\mathrm{M}=706.27 \mathrm{~g} /$ mole): calc. C $39.11, \mathrm{H}$ 5.42, Co 8.34, I 35.94, P 4.39; found C 39.26, H 5.44, Co 7.58, I 37.50, P 4.36.

Synthesis of $\mathrm{CpCoI}_{2}\left\{\mathrm{P}\left[\mathrm{OCH}\left(\mathrm{CF}_{3}\right)_{2}\right]_{3}\right\}$ (4): Following the GP1, $\mathrm{P}\left[\mathrm{OCH}\left(\mathrm{CF}_{3}\right)_{2}\right]_{3}(1.44 \mathrm{~g}$, $2.71 \mathrm{mmol}, 1$ eq.) was dissolved in $\mathrm{CH}_{2} \mathrm{Cl}_{2}(10 \mathrm{~mL})$ and added dropwise to a solution of 
$\mathrm{CpCoI}_{2}(\mathrm{CO})(\mathbf{1}, 1.10 \mathrm{~g}, 2.71 \mathrm{mmol})$ in $\mathrm{CH}_{2} \mathrm{Cl}_{2}(10 \mathrm{~mL})$, during which the evolution of gas was observed. The reaction mixture was stirred for additional $48 \mathrm{~h}$ at $25^{\circ} \mathrm{C}$. Afterwards, the solvent was evaporated, and the residue suspended in $n$-hexane, stirred for a short period of time and filtrated under argon. The isolated blackish solid was dried thoroughly under reduced pressure (yield: $2.22 \mathrm{~g}, 90 \%) .{ }^{1} \mathrm{H}$ NMR $(300 \mathrm{MHz}, \mathrm{CDCl} 3): \delta=5.52(\mathrm{~m}, 3 \mathrm{H})$, $5.51(\mathrm{~d}, 5 \mathrm{H}) \mathrm{ppm} .{ }^{13} \mathrm{C}$ NMR $(75 \mathrm{MHz}, \mathrm{CDCl} 3): \delta=88.9(\mathrm{~d}, J=4.3 \mathrm{~Hz}), 78.1(\mathrm{~d}, J=9.3 \mathrm{~Hz})$, $33.5(\mathrm{~d}, J=3.3 \mathrm{~Hz}), 25.4,23.7 \mathrm{ppm} .{ }^{31} \mathrm{P}$ NMR $(122 \mathrm{MHz}, \mathrm{CDCl} 3): \delta=126.7 \mathrm{ppm} .{ }^{19} \mathrm{~F} \mathrm{NMR}$ (282 MHz, CDCl3): $\delta=-71.9 \mathrm{ppm}$.

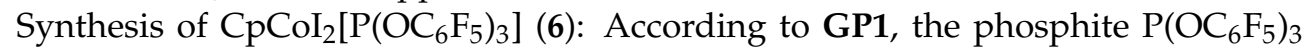
$\left(1.43 \mathrm{~g}, 2.46 \mathrm{mmol}, 1\right.$ eq.) was dissolved in $\mathrm{CH}_{2} \mathrm{Cl}_{2}(10 \mathrm{~mL})$ and then added dropwise to a solution of $\mathrm{CpCoI}_{2}(\mathrm{CO})(\mathbf{1}, 1.0 \mathrm{~g}, 2.46 \mathrm{mmol})$ in $\mathrm{CH}_{2} \mathrm{Cl}_{2}(10 \mathrm{~mL})$. Evolution of gas $(\mathrm{CO})$ was observed during the addition. The reaction mixture was stirred for $96 \mathrm{~h}$ at $25^{\circ} \mathrm{C}$. The reaction work-up was performed by removal of the solvent by evaporation, suspension of the residue suspended in $n$-hexane, stirring for a short period of time and finally filtration under air. The isolated black solid was dried thoroughly under reduced pressure (yield: $1.91 \mathrm{~g}, 81 \%) .{ }^{1} \mathrm{H}$ NMR $(300 \mathrm{MHz}, \mathrm{CDCl} 3): \delta=5.62(\mathrm{~s}, 2 \mathrm{H}), 5.6(\mathrm{~d}, 3 \mathrm{H}) \mathrm{ppm} .{ }^{13} \mathrm{C} \mathrm{NMR}$ (75 MHz, CDCl3): $\delta=89.4,89.01$ ppm. ${ }^{31} \mathrm{P}$ NMR (122 MHz, CDCl3): $\delta=121.1 \mathrm{ppm} .{ }^{19} \mathrm{~F}$ $\operatorname{NMR}(282 \mathrm{MHz}, \mathrm{CDCl}): \delta=-148.0(\mathrm{~d}, J=21.8 \mathrm{~Hz}),-157.2(\mathrm{t}, J=44.5 \mathrm{~Hz}),-161.2(\mathrm{t}$, $J=42.3 \mathrm{~Hz}) \mathrm{ppm}$.

Synthesis of $\mathrm{CpCoI}_{2}\left[\mathrm{P}\left(\mathrm{O}-4-\mathrm{CF}_{3}-\mathrm{C}_{6} \mathrm{H}_{4}\right)_{3}\right]$ (7): Following the GP1, $\mathrm{P}\left(\mathrm{O}-4-\mathrm{CF}_{3}-\mathrm{C}_{6} \mathrm{H}_{4}\right)_{3}$ $\left(1.27 \mathrm{~g}, 2.46 \mathrm{mmol}, 1\right.$ eq.) was dissolved in $\mathrm{CH}_{2} \mathrm{Cl}_{2}(10 \mathrm{~mL})$ and added dropwise to a solution of $\mathrm{CpCoI}_{2}(\mathrm{CO})(1,1.00 \mathrm{~g}, 2.46 \mathrm{mmol})$ in $\mathrm{CH}_{2} \mathrm{Cl}_{2}(10 \mathrm{~mL})$, during which the evolution of gas was observed. The reaction mixture was continued to be stirred for further $16 \mathrm{~h}$ at $25^{\circ} \mathrm{C}$. Afterwards, the solvent was evaporated and the residue suspended in $n$-hexane. After stirring for a short period of time the solid was filtered off under argon and dried thoroughly in vacuo. The product is a black solid (yield: $1.87 \mathrm{~g}, 85 \%) .{ }^{1} \mathrm{H}$ NMR $(300 \mathrm{MHz}$, $\mathrm{CDCl} 3): \delta=7.61-7.48(\mathrm{~m}, 12 \mathrm{H}), 4.98(\mathrm{~m}, 5 \mathrm{H}) \mathrm{ppm} .{ }^{13} \mathrm{C} \mathrm{NMR}(75 \mathrm{MHz}, \mathrm{CDCl} 3): \delta=153.9$, $128.7,128.2,127.3(\mathrm{~m}, J=10.9 \mathrm{~Hz}), 122.1(\mathrm{~d}, J=4.2 \mathrm{~Hz}), 121.8,86.6(\mathrm{~d}, J=3,8 \mathrm{~Hz}) \mathrm{ppm} .{ }^{31} \mathrm{P}$ NMR (122 MHz, CDCl3): $\delta=128.2 \mathrm{ppm} .{ }^{19} \mathrm{~F} \mathrm{NMR} \mathrm{(282} \mathrm{MHz,} \mathrm{CDCl3):} \delta=-62.2 \mathrm{ppm}$.

Synthesis of $\mathrm{CpCoICN}(\mathrm{CO})(8)$ [20]: $\mathrm{CpCo}(\mathrm{CO})_{2}(1.177 \mathrm{~g}, 6.5 \mathrm{mmol})$ was dissolved in diethyl ether $(10 \mathrm{~mL})$ and a solution of cyanogen iodide $(1.0 \mathrm{~g}, 6.5 \mathrm{mmol}, 1 \mathrm{eq}$.) in diethyl ether $(10 \mathrm{~mL})$ was added dropwise, while evolution of $\mathrm{CO}$ gas was taking place. The color of the solution changed from red to brown. The reaction mixture was stirred for additional two hours and then filtrated over a tube frit, washed with diethyl ether $(20 \mathrm{~mL})$ and the solvent was carefully removed in vacuo and the remaining brown solid was dried on air (brown solid, $1.62 \mathrm{~g}, 80 \%$ ). IR: $v_{\max }=3093,2172,1415,1003,828,546,432 \mathrm{~cm}^{-1}$. The spectroscopic data are in accordance to the literature.

Synthesis of CpCoICN[P(Oi-Pr $\left.)_{3}\right]$ (9): Following the GP1, $\mathrm{P}(\mathrm{Oi}-\mathrm{Pr})_{3}(341 \mathrm{mg}, 1.64 \mathrm{mmol}$, 1 eq.) was dissolved in $\mathrm{CH}_{2} \mathrm{Cl}_{2}(10 \mathrm{~mL})$ and added dropwise to a solution of $\mathrm{CpCoICN}(\mathrm{CO})$ $(8,0.5 \mathrm{~g}, 1.64 \mathrm{mmol})$ in $\mathrm{CH}_{2} \mathrm{Cl}_{2}(10 \mathrm{~mL})$, during which the evolution of gas was observed. The reaction mixture was stirred for $20 \mathrm{~h}$ at $25^{\circ} \mathrm{C}$. Afterwards, the solvent was evaporated, and the residue suspended in $n$-hexane, stirred for a short period of time and filtrated under air. The blackish residue was dried under vacuo (yield: $0.745 \mathrm{~g}, 94 \%$ ). ${ }^{1} \mathrm{H}$ NMR (300 MHz, CDCl3): $\delta=5.22(\mathrm{~m}, 5 \mathrm{H}), 4.81(\mathrm{~m}, 3 \mathrm{H}), 1.27(\mathrm{~m}, 18 \mathrm{H}) \mathrm{ppm} .{ }^{13} \mathrm{C} \mathrm{NMR}(75 \mathrm{MHz}$, CDCl3): $\delta=89.3,73.9(\mathrm{~d}, J=9.3 \mathrm{~Hz}), 23.8(\mathrm{~d}, J=5.3 \mathrm{~Hz}) \mathrm{ppm} .{ }^{31} \mathrm{P}$ NMR $(122 \mathrm{MHz}, \mathrm{CDCl} 3)$ : $\delta=126.7$ ppm. IR: $v_{\max }=2979,2930,2145,2119,1370,1174,1142,1099,960,883,844,750$, $708,542,426 \mathrm{~cm}^{-1}$. Elemental analysis for $\mathrm{C}_{14} \mathrm{H}_{26} \mathrm{CoICNO}_{3} \mathrm{P}(\mathrm{M}=485.19 \mathrm{~g} / \mathrm{mole})$ : calc. $\mathrm{C}$ 37.13, H 5.40, Co 12.15, I 26.16, P 6.38; found C 35.36, H 5.46, Co 13.78, I 25.19, P 5.86.

Synthesis of $\mathrm{CpCo}(\mathrm{CN})_{2}\left[\mathrm{P}(\mathrm{O} \text { - }-\mathrm{Pr})_{3}\right]$ (10) [21]: To a solution of complex 2 (228 mg, $0.39 \mathrm{mmol})$ in $\mathrm{MeOH}(10 \mathrm{~mL})$ a solution of $\mathrm{NaCN}(38 \mathrm{mg}, 0.78 \mathrm{mmol})$ in $\mathrm{MeOH}(10 \mathrm{~mL})$ is added dropwise. The reaction mixture was stirred for $22 \mathrm{~h}$ at $25^{\circ} \mathrm{C}$ during which the color changes from a dark red to reddish. Afterwards, the solvent is evaporated, the residue suspended in EtOAc and filtered over a Celite pad yielding a yellow solution. The product is isolated by column chromatography (EtOAc/ $n$-heptane, 30:1 v/v) yielding 
yellow crystals on evaporation of the eluent, which were dried thoroughly under reduced pressure (yield: $122 \mathrm{mg}, 82 \%) .{ }^{1} \mathrm{H} \mathrm{NMR} \mathrm{(300} \mathrm{MHz,} \mathrm{CDCl3):} \delta=5.33(\mathrm{~s}, 5 \mathrm{H}), 5.04-4.85$ (ht, 3H), 1.39 (d, 18H) ppm. ${ }^{13} \mathrm{C} \mathrm{NMR} \mathrm{(300} \mathrm{MHz,} \mathrm{CDCl3):} \delta=90.3(\mathrm{~d}, J=2.1 \mathrm{~Hz}), 74.3(\mathrm{~d}$, $J=8.7 \mathrm{~Hz}), 23.9(\mathrm{~d}, J=3.8 \mathrm{~Hz})$ ppm (the signals for the CN groups could not be detected). ${ }^{31}$ P NMR (500 MHz, CDCl3): $\delta=126.1$ ppm. IR: $v_{\max }=2980,2933,2118,1427,1386,1179$, $1142,1102,1011,968,886,846,761,714,551 \mathrm{~cm}^{-1}$.

Synthesis of $\mathrm{C}_{5} \mathrm{H}_{4} \mathrm{C}(\mathrm{O}) \mathrm{OCH}_{3} \mathrm{CoI}_{2}(\mathrm{CO})$ (14): To a solution of dicobalt octacarbonyl $(6.838 \mathrm{~g}, 20 \mathrm{mmol})$ in THF $(40 \mathrm{~mL})$ solid iodine was added in small portions $(5.076 \mathrm{~g}$, $20 \mathrm{mmol}$ ), during which the evolution of gas was observed. The mixture was stirred for $2 \mathrm{~h}$ and then added dropwise a solution of freshly made sodium cyclopentadienylmethylcarboxylate $(20 \mathrm{mmol})$ via a syringe during which the evolution of gas was observed. The color from the suspension changed from green to brown. It was stirred for $19 \mathrm{~h}$ at room temperature, before the solvent was removed under reduced pressure. The residue was dissolved in methanol $(40 \mathrm{~mL})$ and then solid iodine added in small portions (5.076 $\mathrm{g}$, $20 \mathrm{mmol}$ ). The resulting brown suspension was bubbling heavily and stirred for additional $22 \mathrm{~h}$. The solvent was removed under reduced pressure, the residue dissolved in dichloromethane $(80 \mathrm{~mL})$ and filtrated over a tube frit. The solvent was removed again and the residue filtrated over dry silica gel with THF as the eluent (yield: $1.31 \mathrm{~g}, 14 \%$ ). ${ }^{1} \mathrm{H}$ NMR (300 MHz, CDCl3): $\delta=5.38(\mathrm{t}, 2 \mathrm{H}), 5.18(\mathrm{t}, 2 \mathrm{H}), 3.74(\mathrm{~s}, 3 \mathrm{H}) \mathrm{ppm} .{ }^{13} \mathrm{C} \mathrm{NMR}(75 \mathrm{MHz}$, CDCl3): $\delta=165.0,92.0,87.5,84.7,52.0$ ppm. IR: $v_{\max }=3088,2848,2027,1963,1697,1474$, $1358,1271,1192,1137,970,802,762,614,535 \mathrm{~cm}^{-1}$

Synthesis of $\mathrm{C}_{5} \mathrm{H}_{4} \mathrm{C}(\mathrm{O}) \mathrm{OCH}_{3} \mathrm{CoI}_{2}\left[\mathrm{P}(\mathrm{Oi}-\mathrm{Pr})_{3}\right]($ 15): Following the synthesis protocol for complex 2, $\mathrm{P}(\mathrm{O} i-\mathrm{Pr})_{3}(121 \mathrm{mg}, 0.582 \mathrm{mmol}, 1$ eq. $)$ was dissolved in $\mathrm{CH}_{2} \mathrm{Cl}_{2}(10 \mathrm{~mL})$ and added dropwise to a solution of $\mathrm{C}_{5} \mathrm{H}_{4} \mathrm{C}(\mathrm{O}) \mathrm{OCH}_{3} \mathrm{CoI}_{2}(\mathrm{CO})(\mathbf{1 4}, 0.27 \mathrm{~g}, 0.582 \mathrm{mmol})$ in $\mathrm{CH}_{2} \mathrm{Cl}_{2}(10 \mathrm{~mL})$, during which the evolution of gas was observed. The reaction mixture was stirred for $20 \mathrm{~h}$ at $25^{\circ} \mathrm{C}$. Afterwards, the solvent was removed under reduced pressure and the residue was filtrated over dry silica gel with $n$-hexane. The collected black solid was dried thoroughly under reduced pressure (yield: $0.325 \mathrm{~g}, 88 \%) .{ }^{1} \mathrm{H} \mathrm{NMR}(300 \mathrm{MHz}$, CDCl3): $\delta=5.19(\mathrm{t}, 5 \mathrm{H}), 4.66(\mathrm{~s}, 3 \mathrm{H}), 3.67(\mathrm{~d}, J=20.5 \mathrm{~Hz}, 5 \mathrm{H}), 1.19(\mathrm{~s}, 18 \mathrm{H}) \mathrm{ppm} .{ }^{13} \mathrm{C}$ NMR (75 MHz, CDCl3): $\delta=87.5,85.9,84.7,82.6,69.7,24.02(\mathrm{~d}, J=3.3 \mathrm{~Hz}) \mathrm{ppm} .{ }^{31} \mathrm{P}$ NMR $(122 \mathrm{MHz}, \mathrm{CDCl}): \delta=162.2$ ppm. IR: $v_{\max }=2977,2030,1933,1712,1479,1373,1271,1136$, $957,878,766,537 \mathrm{~cm}^{-1}$.

Synthesis of $\left\{\mathrm{CpCo}\left[\mathrm{P}(\mathrm{O} i-\mathrm{Pr})_{3}\right]\left(\mathrm{NCMe}_{2}\right\}\left(\mathrm{BF}_{4}\right)_{2}\right.$ (21) [21]: Precatalyst 10 (60.1 mg, $0.16 \mathrm{mmol})$ and $(\mathrm{Me})_{3} \mathrm{OBF}_{4}(55.0 \mathrm{mg}, 0.31 \mathrm{mmol})$ are weighed into a Schlenk flask in an Argon filled glovebox. The compounds are dissolved in a minimum amount of DCM and refluxed at $55^{\circ} \mathrm{C}$ under argon for $6 \mathrm{~h}$. The solution is filtered over a Celite pad and the solvent is removed under reduced pressure yielding compound $\mathbf{2 1}$ as a pale-yellow powder (yield: $86.6 \mathrm{mg}, 94 \%) .{ }^{1} \mathrm{H}$ NMR (500 MHz, D $\left.2 \mathrm{O}\right): \delta=6.08(\mathrm{~s}, 5 \mathrm{H}), 5.00-4.89$ (ht, 3H), 3.66 $(\mathrm{s}, 6 \mathrm{H}), 1.43(\mathrm{~d}, J=6.12 \mathrm{~Hz}, 18 \mathrm{H}) \mathrm{ppm} .{ }^{13} \mathrm{C}$ NMR $\left(500 \mathrm{MHz}, \mathrm{D}_{2} \mathrm{O}\right): \delta=94.0,92.4,78.2(\mathrm{~d}$, $J=10.14 \mathrm{~Hz}), 31.4,23.03 \mathrm{ppm}) .{ }^{31} \mathrm{P} \mathrm{NMR}\left(500 \mathrm{MHz}, \mathrm{D}_{2} \mathrm{O}\right): \delta=107.8 \mathrm{ppm}$. IR: $v_{\max }=3121$, 2993, 2924, 2852, 2270, 1454, 1436, 1414, 1386, 1379, 1284, 1180, 1144, 1046, 1035, 978, 874, $835,752 \mathrm{~cm}^{-1}$. Melting Point: $138^{\circ} \mathrm{C}$.

\subsection{General Procedure 2 for Catalyst Screening Reactions with Triyne 16 (Table 1)}

The $\mathrm{CpCo}(\mathrm{III})$ precatalyst (1-10, 14, 15 or $\mathrm{CpCo}(\mathrm{CO})_{2}$, with $10 \mathrm{~mol} \%$ catalyst loading with regard to triyne) was added to a solution of triyne 16 (1 eq.) in toluene and was stirred at the given reaction temperature for a specific time. After cooling to room temperature, the solvent was removed and purified by column chromatography to give the product, which was identified by NMR.

Precatalyst 1 (Table 1, entry 1): Complex 1 ( $25 \mathrm{mg}, 0.0616 \mathrm{mmol}, 10 \mathrm{~mol} \%$ ) and 16 $(100 \mathrm{mg}, 0.616 \mathrm{mmol})$ were heated in toluene at $75^{\circ} \mathrm{C}$ for $19 \mathrm{~h}$, yielding $38 \mathrm{mg}(38 \%)$ of $16 \mathrm{cycl}$ and $32 \mathrm{mg}(32 \%)$ of unreacted 16 was recovered. 
Precatalyst 2 (Table 1, entry 2): Complex 2 (36 mg, $0.0616 \mathrm{mmol}, 10 \mathrm{~mol} \%$ ) and 16 $(100 \mathrm{mg}, 0.616 \mathrm{mmol})$ were heated in toluene at $75^{\circ} \mathrm{C}$ for $22 \mathrm{~h}$, yielding $55 \mathrm{mg}(55 \%)$ of 16cycl and $7 \mathrm{mg}(7 \%)$ of unreacted 16 were recovered.

Precatalyst 3 (Table 1, entry 3): Complex 3 (43 mg, $0.0616 \mathrm{mmol}, 10 \mathrm{~mol} \%$ ) and 16 $(100 \mathrm{mg}, 0.616 \mathrm{mmol})$ were heated in toluene at $75{ }^{\circ} \mathrm{C}$ for $20 \mathrm{~h}$, yielding $22 \mathrm{mg}(22 \%)$ of 16 cycl and $27 \mathrm{mg}(27 \%)$ of unreacted 16 was recovered.

Precatalyst 4 (Table 1, entry 4): Complex 4 (56 mg, $0.0616 \mathrm{mmol}, 10 \mathrm{~mol} \%$ ) and 16 $(100 \mathrm{mg}, 0.616 \mathrm{mmol})$ were heated in toluene at $75^{\circ} \mathrm{C}$ for $21 \mathrm{~h}$, yielding $27 \mathrm{mg}(27 \%)$ of $\mathbf{1 6 c y c l}$ and $34 \mathrm{mg}(34 \%)$ of unreacted 16 was recovered.

Precatalyst 6 (Table 1, entry 5): Complex 5 (59 mg, $0.0616 \mathrm{mmol}, 10 \mathrm{~mol} \%$ ) and 16 $(100 \mathrm{mg}, 0.616 \mathrm{mmol})$ were heated in toluene at $75{ }^{\circ} \mathrm{C}$ for $21 \mathrm{~h}$, yielding $25 \mathrm{mg}(25 \%)$ of $16 c y c l$ and $60 \mathrm{mg}(60 \%)$ of unreacted 16 was recovered.

Precatalyst 7 (Table 1, entry 6): Complex 7 (55 mg, $0.0616 \mathrm{mmol}, 10 \mathrm{~mol} \%$ ) and 16 $(100 \mathrm{mg}, 0.616 \mathrm{mmol})$ were heated in toluene at $75{ }^{\circ} \mathrm{C}$ for $21 \mathrm{~h}$, yielding $8 \mathrm{mg}(8 \%)$ of $16 \mathrm{cycl}$ and $60 \mathrm{mg}(60 \%)$ of unreacted 16 was recovered.

Precatalyst 8 (Table 1, entry 7): Complex 8 (18.8 mg, $0.0616 \mathrm{mmol}, 10 \mathrm{~mol} \%)$ and 16 $(100 \mathrm{mg}, 0.616 \mathrm{mmol})$ were heated in toluene at $75^{\circ} \mathrm{C}$ for $14 \mathrm{~h} ; 88 \mathrm{mg}(88 \%)$ of unreacted 16 was recovered.

Precatalyst 9 (Table 1, entry 8): Complex 9 (29.8 mg, $0.0616 \mathrm{mmol}, 10 \mathrm{~mol} \%)$ and 16 $(100 \mathrm{mg}, 0.616 \mathrm{mmol})$ were heated in toluene at $75^{\circ} \mathrm{C}$ for $21 \mathrm{~h} ; 82 \mathrm{mg}(82 \%)$ of unreacted 16 were recovered.

Precatalyst 9 (Table 1, entry 9): Complex 9 (29.8 mg, $0.0616 \mathrm{mmol}, 10 \mathrm{~mol} \%$ ) and 16 $(100 \mathrm{mg}, 0.616 \mathrm{mmol})$ were heated in toluene at $100{ }^{\circ} \mathrm{C}$ for $23 \mathrm{~h} ; 85 \mathrm{mg}(85 \%)$ of unreacted 16 was recovered.

Precatalyst 10 (Table 1, entry 10): Complex 10 (3.7 mg, $0.01 \mathrm{mmol}, 10 \mathrm{~mol} \%)$ and 16 $(16.5 \mathrm{mg}, 0.1 \mathrm{mmol})$ were heated in toluene at $75^{\circ} \mathrm{C}$ for $21 \mathrm{~h}$, leading to isolation of $14.8 \mathrm{mg}$ (90\%) of unreacted 16 and $3.5 \mathrm{mg}$ of complex $10(95 \%)$.

Precatalyst 10 (Table 1, entry 11): Complex 10 (3.8 mg, $0.01 \mathrm{mmol}, 10 \mathrm{~mol} \%)$ and 16 $(16.5 \mathrm{mg}, 0.1 \mathrm{mmol})$ were heated in toluene at $105{ }^{\circ} \mathrm{C}$ for $21 \mathrm{~h}$, yielding $13.9 \mathrm{mg}(84 \%)$ of 16cycl and $2.1 \mathrm{mg}(12 \%)$ of unreacted 16 was recovered

Precatalyst 14 (Table 1, entry 12): Complex 14 (28.6 mg, $0.0616 \mathrm{mmol}, 10 \mathrm{~mol} \%)$ and $16(100 \mathrm{mg}, 0.616 \mathrm{mmol})$ were heated in toluene at $75^{\circ} \mathrm{C}$ for $16 \mathrm{~h}$, yielding $48 \mathrm{mg}(48 \%)$ of 16cycl as well as $25 \mathrm{mg}(25 \%)$ of unreacted 16 was recovered.

Precatalyst 15 (Table 1, entry 13): Complex 15 (40.0 mg, $0.0616 \mathrm{mmol}, 10 \mathrm{~mol} \%$ ) and $16(100 \mathrm{mg}, 0.616 \mathrm{mmol})$ were heated in toluene at $75^{\circ} \mathrm{C}$ for $20 \mathrm{~h}$, yielding $44 \mathrm{mg}(44 \%)$ of $16 c y c l$ and no unreacted 16 was recovered.

Precatalyst $\mathrm{CpCo}(\mathrm{CO})_{2}$ : Reaction of $\mathrm{CpCo}(\mathrm{CO})_{2}(11.1 \mathrm{mg}, 0.0616 \mathrm{mmol})$ with triyne 16 (100 mg, $0.616 \mathrm{mmol})$ gave no conversion to $16 \mathrm{cycl}$ at all.

\subsection{General Procedure 3 for Microwave Reactions with Precatalyst 2 (Table 2 and Scheme 4)}

$\mathrm{CpCo}(\mathrm{III})$ precatalyst 2 (with 10 or $20 \mathrm{~mol} \%$ catalyst loading with regard to triyne) was added to a solution of triyne $\mathbf{1 6}$ (1 eq.) in toluene and subjected to a microwave oven and heated under stirring at the given reaction temperature for a specific time. After the reaction the solvent was removed, and the crude product purified by column chromatography over silica gel.

Table 2, entry 1: Complex 2 (36 mg, $0.0616 \mathrm{mmol}, 10 \mathrm{~mol} \%$ ) and 16 (100 mg, $0.616 \mathrm{mmol})$ were reacted in the microwave oven in toluene at $100{ }^{\circ} \mathrm{C}$ for $4 \mathrm{~h}$, yielding $25 \mathrm{mg}(25 \%)$ of $16 \mathrm{cycl}$ and $17 \mathrm{mg}(17 \%)$ of unreacted 16 was recovered.

Table 2, entry 2: Complex 2 (36 mg, $0.0616 \mathrm{mmol}, 10 \mathrm{~mol} \%$ ) and 16 (100 mg, $0.616 \mathrm{mmol})$ were reacted in the microwave oven in toluene at $100{ }^{\circ} \mathrm{C}$ for $12 \mathrm{~h}$, yielding $41 \mathrm{mg}(41 \%)$ of 16cycl and $7 \mathrm{mg}$ (7\%) of unreacted 16 was recovered.

Table 2, entry 3: Complex 2 (72 mg, $0.1232 \mathrm{mmol}, 20 \mathrm{~mol} \%$ ) and 16 (100 mg, $0.616 \mathrm{mmol})$ were reacted in the microwave oven in toluene at $100{ }^{\circ} \mathrm{C}$ for $4 \mathrm{~h}$, yielding $56 \mathrm{mg} \mathrm{(56 \% )} \mathrm{of}$ $\mathbf{1 6 c y c l}$ and $7 \mathrm{mg}$ (7\%) of unreacted 16 was recovered. 
Table 2, entry 4: Complex 2 (36 mg, $0.0616 \mathrm{mmol}, 10 \mathrm{~mol} \%)$, AgOAc (21 mg, $0.123 \mathrm{mmol}$, $20 \mathrm{~mol} \%)$ and $16(100 \mathrm{mg}, 0.616 \mathrm{mmol})$ were heated in toluene at $75^{\circ} \mathrm{C}$ for $18 \mathrm{~h}$, yielding $20 \mathrm{mg}(20 \%)$ of $\mathbf{1 6 c y c l}$ and $58 \mathrm{mg}(58 \%)$ of unreacted 16 was recovered.

Table 2, entry 5: Complex 2 (36 mg, $0.0616 \mathrm{mmol}, 10 \mathrm{~mol} \%)$, AgOAc (10.5 mg, $0.0616 \mathrm{mmol}, 10 \mathrm{~mol} \%)$ and $16(100 \mathrm{mg}, 0.616 \mathrm{mmol})$ were heated in toluene at $75{ }^{\circ} \mathrm{C}$ for $18 \mathrm{~h}$, yielding $5 \mathrm{mg}$ (5\%) of $\mathbf{1 6 c y c l}$ and $74 \mathrm{mg}$ (74\%) of unreacted 16 was recovered.

Table 2, entry 6: Complex 2 (36 mg, $0.0616 \mathrm{mmol}, 10 \mathrm{~mol} \%$ ) and 16 (100 mg, $0.616 \mathrm{mmol})$ were heated in toluene at $100{ }^{\circ} \mathrm{C}$ for $12 \mathrm{~h}$ after cooling to room temperature, complex 2 (36 mg, $0.0616 \mathrm{mmol}, 10 \mathrm{~mol} \%$ ) was added again and heated at $100{ }^{\circ} \mathrm{C}$ for $12 \mathrm{~h}$, yielding $43 \mathrm{mg}(43 \%)$ of $16 \mathrm{cycl}$ and $15 \mathrm{mg}(15 \%)$ of unreacted 16 was recovered.

Table 2, entry 7: Complex 2 (36 mg, $0.0616 \mathrm{mmol}, 10 \mathrm{~mol} \%$ ), zinc powder (4 mg, $0.0616 \mathrm{mmol}, 10 \mathrm{~mol} \%)$ and $16(100 \mathrm{mg}, 0.616 \mathrm{mmol})$ were heated in toluene at $75{ }^{\circ} \mathrm{C}$ for $48 \mathrm{~h}$, yielding $53 \mathrm{mg}(53 \%)$ of $\mathbf{1 6 c y c l}$ and $8 \mathrm{mg} \mathrm{(8 \% )} \mathrm{of} \mathrm{unreacted} 16$ was recovered.

Scheme 4, Exp. 4_2: Complex 2 (19 mg, $0.0318 \mathrm{mmol}, 10 \mathrm{~mol} \%)$ and 17 (100 mg, $0.318 \mathrm{mmol}$ ) were reacted in the microwave oven in toluene at $140{ }^{\circ} \mathrm{C}$ for $4 \mathrm{~h}$, yielding $75 \mathrm{mg}(75 \%)$ of $\mathbf{1 7 c y c l}$ and $10 \mathrm{mg}(10 \%)$ of unreacted 17 was recovered. Exp $4 \_1$ was performed following General Procedure 2 at 75 and $100{ }^{\circ} \mathrm{C}$, giving a yield for $17 \mathrm{cycl}$ of $24 \%$ (24 mg).

\subsection{Synthesis and Reactions with Methylated Complexes 2 and 9 (Schemes 5 and 6)}

Reaction of $\mathrm{CpCoI}_{2}\left[\mathrm{P}(\mathrm{O} i \text {-Pr })_{3}\right]$ with $\mathrm{MeMgBr}$ and subsequent cyclization (2-Me): Complex $2(0.84 \mathrm{~g}, 1.43 \mathrm{mmol})$ was dissolved in $10 \mathrm{~mL}$ THF in a Schlenk flask. After cooling to $-78{ }^{\circ} \mathrm{C}, \mathrm{MeMgBr}\left(3 \mathrm{M}\right.$ in $\mathrm{Et}_{2} \mathrm{O}, 0.96 \mathrm{~mL}, 2.86 \mathrm{mmol}, 2 \mathrm{eq}$.) was added gradually via syringe to the solution, whose color changed from violet to light brown. After additional stirring for $3 \mathrm{~h}$ at $-78{ }^{\circ} \mathrm{C}$, the obtained suspension was filtered, and the residue dried under vacuo to give a brown oil, which solidified. Attempted crystallization from toluene, THF, diethyl ether, dichloromethane and n-pentane and mixtures of solvents did not give solid 2-Me for further characterization.

Cyclization of 16 using 2-Me (Scheme 5): The reaction product 2-Me obtained prior $(22.3 \mathrm{mg}, 0.0616 \mathrm{mmol}$, estimated $10 \mathrm{~mol} \%)$ was directly reacted with triyne 16 (100 mg, $0.616 \mathrm{mmol}$ ) according to the General Procedure 2 by heating in toluene at $75^{\circ} \mathrm{C}$ for $18 \mathrm{~h}$, yielding $41 \mathrm{mg}$ (41\%) of 16cycl.

Cyclization of 1,6-heptadiyne and benzonitrile using 2-Me (Scheme 5): The reaction product 2-Me (18 mg, $0.05 \mathrm{mmol}$, estimated $10 \mathrm{~mol} \%$ ) was directly reacted with $1,6-$ heptadiyne (46 mg, $0.5 \mathrm{mmol}$ ) and benzonitrile $(257 \mathrm{mg}, 2.5 \mathrm{mmol})$ according to the General Procedure 2 by heating in toluene at $75{ }^{\circ} \mathrm{C}$ for $20 \mathrm{~h}$, yielding pyridine 19 with $30 \%$ (29 mg) yield.

Synthesis towards $\mathrm{CpCo}(\mathrm{CN}) \mathrm{Me}\left[\mathrm{P}(\mathrm{Oi}-\mathrm{Pr})_{3}\right]$ (9-Me): Complex 9 (30 mg, $\left.0.062 \mathrm{mmol}\right)$ was dissolved in $3 \mathrm{~mL}$ THF in a Schlenk flask. After cooling to $-78{ }^{\circ} \mathrm{C}, \mathrm{MeMgBr}(3 \mathrm{M}$ in $\mathrm{Et}_{2} \mathrm{O}, 0.02 \mathrm{~mL}, 0.062 \mathrm{mmol}, 1$ eq.) was added gradually via syringe to the solution, whose color changed from violet to light brown. After additional stirring for $3 \mathrm{~h}$ at $-78{ }^{\circ} \mathrm{C}$, the obtained suspension was filtered, and the residue dried under vacuo to give a brownish solid. NMR analysis $\left({ }^{1} \mathrm{H},{ }^{13} \mathrm{P}\right)$ confirmed conversion of 9 . The crude product was directly used in the next step.

Cyclization of 16 using complex 9-Me (Scheme 6): The reaction product 9-Me (23 mg, $0.0616 \mathrm{mmol}, 10 \mathrm{~mol} \%)$ was reacted with triyne $16(100 \mathrm{mg}, 0.616 \mathrm{mmol})$ according to the General Procedure 2 by heating in toluene at $75^{\circ} \mathrm{C}$ for $18 \mathrm{~h}$, yielding $61 \mathrm{mg}(61 \%)$ of $16 \mathrm{cycl}$. Repeating the same procedure at $100{ }^{\circ} \mathrm{C}$ reaction temperature led to the isolation of $16 \mathrm{cycl}$ with $74 \%$ (74 mg) yield.

Cyclization of 1,6-heptadiyne and benzonitrile using complex 9-Me (Scheme 6): The reaction product 9-Me (23 $\mathrm{mg}, 0.0616 \mathrm{mmol}, 10 \mathrm{~mol} \%$ ) was reacted with 1,6-heptadiyne (60 mg, $0.616 \mathrm{mmol})$ and benzonitrile $(317 \mathrm{mg}, 3.08 \mathrm{mmol}$ ) according to the General Procedure 2 by heating in toluene at $100{ }^{\circ} \mathrm{C}$ for $24 \mathrm{~h}$, yielding pyridine 19 with $24 \%$ (26 mg) yield. 


\subsection{Scavenger Experiment for Reductive Elimination Process (Scheme 7)}

Experiment using complex 10: In an Argon filled glovebox complex 10 (39.3 mg, $0.1 \mathrm{mmol})$ and dimethylfumarate $(15.2 \mathrm{mg}, 0.1 \mathrm{mmol})$ were weighed into a Schlenk flask and dissolved in a minimum amount of toluene resulting in a yellow solution. The reaction was heated in an oil bath to $105{ }^{\circ} \mathrm{C}$ and stirred for $21 \mathrm{~h}$. Afterwards the solvent was evaporated, and column chromatography was performed (EtOAc/MeOH, 5:1 v/v) leading to quantitative reisolation of both, complex 10 and dimethylfumarate.

\subsection{Reactivity of Precatalyst 2 in the Presence of $\mathrm{AgBF}_{4}$ (Scheme 9)}

Triyne 16 as substrate, heating with oil bath at $75^{\circ} \mathrm{C}$ : According to General Procedure 2, precatalyst 2 (36 mg, $0.0616 \mathrm{mmol}, 10 \mathrm{~mol} \%)$, triyne $16(100 \mathrm{mg}, 0.616 \mathrm{mmol})$ and finally $\mathrm{AgBF}_{4}(24 \mathrm{mg}, 0.123 \mathrm{mmol}, 20 \mathrm{~mol} \%)$ were mixed in toluene and the reaction solution became turbid. The reaction suspension was heated at $75^{\circ} \mathrm{C}$ for $21 \mathrm{~h}$, yielding $28 \mathrm{mg}(28 \%)$ of $16 \mathrm{cycl}$ and $42 \mathrm{mg}$ ( $42 \%$ ) of unreacted 16 was recovered.

Triyne 17 as substrate, heating with microwave at $140^{\circ} \mathrm{C}$ : Following General Procedure 3, precatalyst $2(37 \mathrm{mg}, 0.0636 \mathrm{mmol}, 10 \mathrm{~mol} \%)$, triyne $17(200 \mathrm{mg}, 0.636 \mathrm{mmol})$ and finally $\mathrm{AgBF}_{4}(25 \mathrm{mg}, 0.1272 \mathrm{mmol}, 20 \mathrm{~mol} \%)$ were mixed in toluene and the reaction solution became turbid. The reaction suspension was heated at $140{ }^{\circ} \mathrm{C}$ for $4 \mathrm{~h}$ in the microwave, yielding $90 \mathrm{mg}(45 \%)$ of $\mathbf{1 7 c y c l}$ and $72 \mathrm{mg}$ (36\%) of unreacted $\mathbf{1 7}$ was recovered.

\subsection{Reactivity of Isolated Precatalyst 21 (Scheme 11):}

Reaction of triyne 16 at $75{ }^{\circ} \mathrm{C}$ : Complex $21(5.8 \mathrm{mg}, 0.01 \mathrm{mmol}, 10 \mathrm{~mol} \%)$ and 16 $\left(17.1 \mathrm{mg}, 0.10 \mathrm{mmol}\right.$ ) were heated in toluene at $75^{\circ} \mathrm{C}$ for $21 \mathrm{~h}$, giving $15.8 \mathrm{mg}(92 \%)$ of unreacted 16 as well as reisolated catalyst.

Reaction of triyne 16 at $105{ }^{\circ} \mathrm{C}$ : Complex $21(5.8 \mathrm{mg}, 0.01 \mathrm{mmol}, 10 \mathrm{~mol} \%)$ and $\mathbf{1 6}$ $\left(17.0 \mathrm{mg}, 0.10 \mathrm{mmol}\right.$ ) were heated in toluene at $105^{\circ} \mathrm{C}$ for $21 \mathrm{~h}$, yielding $9.8 \mathrm{mg}(57 \%)$ of $16 \mathrm{cycl}$ and $6.1 \mathrm{mg}(36 \%)$ of unreacted 16 was recovered.

Reaction of triyne 17 at $75^{\circ} \mathrm{C}$ : Complex $21(5.8 \mathrm{mg}, 0.01 \mathrm{mmol}, 10 \mathrm{~mol} \%)$ and 17 (31.5 mg, $0.10 \mathrm{mmol}$ ) were heated in toluene at $75{ }^{\circ} \mathrm{C}$ for $21 \mathrm{~h}$, giving $28.7 \mathrm{mg}(91 \%)$ of unreacted 17 as well as reisolated catalyst.

Reaction of triyne 17 at $105{ }^{\circ} \mathrm{C}$ : Complex $21(5.9 \mathrm{mg}, 0.01 \mathrm{mmol}, 10 \mathrm{~mol} \%)$ and $\mathbf{1 7}$ $(31.4 \mathrm{mg}, 0.10 \mathrm{mmol})$ were heated in toluene at $105{ }^{\circ} \mathrm{C}$ for $21 \mathrm{~h}$, yielding $1.6 \mathrm{mg} \mathrm{(5 \% )} \mathrm{of}$ $17 \mathrm{cycl}$ and $28.0 \mathrm{mg}(89 \%)$ of unreacted $\mathbf{1 7}$ was recovered.

\section{Summary}

In this work, we described the synthesis and use of $\mathrm{CpCo}(\mathrm{III})$ complexes as precatalysts for cyclotrimerization reactions preferably of triynes, which usually rely on $\mathrm{CpCo}(\mathrm{I})$ precursor complexes. The reactivity behavior is interesting because cyclizations already occur at $75^{\circ} \mathrm{C}$, however, for more complete conversions higher temperatures are needed. In addition, a significant part of triyne starting material is clearly converted to byproduct(s), which were not identified and may consist of polymeric materials, which is unusual to observe with $\mathrm{CpCo}$ (phosphite)-based catalysts for these substrates under the reaction conditions used. All investigated $\mathrm{CpCoI}_{2}$ (ligand) complexes stabilized by neutral ligands like $\mathrm{CO}$ or phosphite showed reactivity, with $\mathrm{CO}$ and $\mathrm{P}(\mathrm{O} i-\mathrm{Pr})_{3}$ giving the best results, while cyano or mixed iodo/cyano complexes gave no product formation at $75{ }^{\circ} \mathrm{C}$ reaction temperature. However, at $105^{\circ} \mathrm{C}$ the dicyano complex $\mathrm{CpCo}(\mathrm{CN})_{2}\left[\mathrm{P}(\mathrm{O} i-\mathrm{Pr})_{3}\right]$ gave excellent conversion of the triyne screening substrate.

The catalytic behavior in the present investigation therefore seems to be dominated by the anionic ligands, iodide and cyanide, corroborating the important role for the reactivity of the precatalyst. Removal of iodide (by $\mathrm{AgBF}_{4}$ ) or cyanide (by alkylation with Meerwein salt) from the $\mathrm{CpCo}(\mathrm{III})$ compounds led to complexes with different reactivity towards alkynes at identical temperatures. On the other hand, the alkylation reaction of the iodo/cyano complex with $\mathrm{MeMgBr}$ led to complexes with increased reactivity for the cyclization of the terminal triyne testing substrate. finally giving the best results. 
Taken together the experimental results demonstrated the ability of such $\mathrm{CpCo}(\mathrm{III})$ complexes to be suitable catalysts for cyclotrimerization reactions even without reduction. The conducted experiments also provided evidence to exclude simple reductive elimination of the anionic ligands to yield active $\mathrm{CpCo}(\mathrm{I})$ catalysts, which are known to mediate $[2+2+2]$ cycloaddition reactions. Testing the reactions under reducing conditions in the presence of zinc at $75{ }^{\circ} \mathrm{C}$ gave only a very slightly different yield. Isolated $\mathrm{CpCo}(\mathrm{I})$ precatalysts are usually more active for the cyclization of nitriles and diynes, which was not found in our presented study, while on the other hand the yields received for cyclization of triynes are lower than those for the most active catalysts observed in the presented study [16]. Therefore, the observed discrepancy of reactivities might be indeed credited to $\mathrm{CpCo}(\mathrm{III})$ complexes as active species, and detailed studies are in progress in our laboratory to confirm the oxidation state of the active species.

Supplementary Materials: The following are available online at https:/ / www.mdpi.com/article/ 10.3390/catal11050596/s1: NMR spectra $\left({ }^{1} \mathrm{H},{ }^{13} \mathrm{C},{ }^{31} \mathrm{P},{ }^{19} \mathrm{~F}\right)$ for compounds $\mathbf{2 - 4}, \mathbf{6 - 1 0}, \mathbf{1 4}, \mathbf{1 5}, 21$ and cyclization products $16 \mathrm{cycl}$ and $17 \mathrm{cycl}$; NMR reaction control spectra for the synthesis of compound 9-Me; NMR reaction control spectra for the stoichiometric reaction of complex 2 and triyne $\mathbf{1 6}$ (Scheme 8).

Author Contributions: Experimental work, F.F. and M.E.; writing-original draft preparation, M.H.; supervision, M.H. All authors have read and agreed to the published version of the manuscript.

Funding: We thank the Leibniz-Gemeinschaft, the LIKAT Rostock and the Johannes Kepler University Linz for financial support. Open Access Funding by the University of Linz.

Acknowledgments: We thank Tobias Pientka for the initial synthesis of complexes $\mathbf{2}$ and $\mathbf{3}$ and preliminary cyclization screening experiments.

Conflicts of Interest: The authors declare no conflict of interest.

\section{References}

1. Yoshino, T.; Satake, S.; Matsunaga, S. Diverse Approaches for Enantioselective C-H Functionalization Reactions Using Group 9 Cp ${ }^{\mathrm{x}} \mathrm{M}^{\mathrm{III}}$ Catalysts. Chem. Eur. J. 2020, 26, 7346-7357. [CrossRef] [PubMed]

2. Loginov, D.A.; Shul'pina, L.S.; Muratov, D.V.; Shul'pin, G.B. Cyclopentadienyl cobalt(III) complexes: Synthetic and catalytic chemistry. Coord. Chem. Rev. 2019, 387,1-31. [CrossRef]

3. Pagano, J.K.; Stelmach, J.P.W.; Waterman, R. Cobalt-catalyzed ammonia borane dehydrocoupling and transfer hydrogenation under aerobic conditions. Dalton Trans. 2015, 44, 12074-12077. [CrossRef] [PubMed]

4. Contakes, S.M.; Klausmeyer, K.K.; Rauchfuss, T.B. Cyanide compounds. Tricyanometalate building blocks and organometallic cyanide cages. Inorg. Synth. 2004, 34, 166-171.

5. King, R.B. Organometallic Chemistry of the Transition Metals. XI. Some New Cyclopentadienyl Derivatives of Cobalt and Rhodium. Inorg. Chem. 1966, 5, 82-87. [CrossRef]

6. Gardner, S.A.; Rausch, M.D. Reactions of $\pi$-cyclopentadienyltriphenylphosphinemetal diiodides and $\pi$-cyclopentadienylcarbonylmetal diiodides ( $\mathrm{M}=\mathrm{Co}$, Rh, Ir) with 1,4-dilithio-1,2,3,4-tetraphenylbutadiene. J. Organomet. Chem. 1974, 78, 415-421. [CrossRef]

7. Avilés, T.; Dinis, A.; Calhorda, M.J.; Pinto, P.; Félix, V.; Drew, M.G.B. Synthesis, X-ray structure, and theoretical studies of novel cationic mono-cyclopentadienyl complexes of Co(III): The orthometalation of trans-azobenzene. J. Organomet. Chem. 2001, 625, 186-194. [CrossRef]

8. Kotha, S.; Lahiri, K.; Sreevani, G. Design and Synthesis of Aromatics through [2 + 2 + 2] Cyclotrimerization. Synlett 2018, 29, 2342-2361. [CrossRef]

9. Babazadeh, M.; Soleimani-Amiri, S.; Vessally, E.; Hosseinian, A.; Edjlali, L. Transition metal-catalyzed [2+2 + 2] cycloaddition of nitrogen-linked 1,6-diynes: A straightforward route to fused pyrrolidine systems. RSC Adv. 2017, 7, 43716-43736. [CrossRef]

10. Thakur, A.; Louie, J. Advances in Nickel-Catalyzed Cycloaddition Reactions to Construct Carbocycles and Heterocycles. Acc. Chem. Res. 2015, 48, 2354-2365. [CrossRef]

11. Amatore, M.; Aubert, C. Recent Advances in Stereoselective [2 + $2+2]$ Cycloadditions. Eur. J. Org. Chem. 2015, 2015, 265-286. [CrossRef]

12. Okamoto, S.; Sugiyama, Y. From the Development of Catalysts for Alkyne and Alkyne-Nitrile [2 + $2+2]$ Cycloaddition Reactions to Their Use in Polymerization Reactions. Synlett 2013, 24, 1044-1060. [CrossRef]

13. Shibata, Y.; Tanaka, K. Rhodium-Catalyzed [2 + 2 +2] Cycloaddition of Alkynes for the Synthesis of Substituted Benzenes: Catalysts, Reaction Scope, and Synthetic Applications. Synthesis 2012, 44, 323-350. [CrossRef]

14. Okamoto, S. Synthesis of 2,2'-Bipyridines by Transition Metal-Catalyzed Alkyne/Nitrile [2+2+2] Cycloaddition Reactions. Heterocycles 2012, 85, 1579-1602. [CrossRef] 
15. Broere, D.L.J.; Ruijter, E. Recent Advances in Transition-Metal-Catalyzed [2 + 2 + 2]-Cyclo(co)trimerization Reactions. Synthesis 2012, 44, 2639-2672. [CrossRef]

16. Thiel, I.; Jiao, H.; Spannenberg, A.; Hapke, M. Fine-Tuning the Reactivity and Stability by Systematic Ligand Variations in CpCo Complexes as Catalysts for [2 + 2 +2] Cycloaddition Reactions. Chem. Eur. J. 2013, 19, 2548-2554. [CrossRef]

17. Towle, D.K.; Landon, S.J.; Brill, T.B.; Tulip, T.H. A double Michaelis-Arbusov rearrangement involving ( $\eta^{5}$-cyclopentadienyl)(carbonyl)diiodocobalt and trimethyl phosphite. Formation of the cobalt "supersandwich" complex. Organometallics 1982, 1, $295-301$. [CrossRef]

18. Dineen, J.A.; Pauson, P.L. Cyanide and isocyanide metal complexes: III. Further studies of the alkylation of cyano groups in cyclopentadienyl-cobalt and -iron complexes. J. Organomet. Chem. 1974, 71, 77-85. [CrossRef]

19. Fischer, F.; Pientka, T.; Jiao, H.; Spannenberg, A.; Hapke, M. CpCo(I) precatalysts for [2+2 + 2] cycloaddition reactions: Synthesis and reactivity. Catal. Sci. Technol. 2020, 10, 8005-8014. [CrossRef]

20. Morán, M. Reactions of $\left(\eta^{5}-\mathrm{C}_{5} \mathrm{H}_{5}\right) \mathrm{Co}(\mathrm{CO})_{2}$ and $\left(\eta^{5}-\mathrm{EtMe}_{4} \mathrm{C}_{5}\right) \mathrm{Co}(\mathrm{CO})_{2}$ with Iodine and Cyanogen Halides, $\mathrm{XCN}(\mathrm{X}=\mathrm{Br} \mathrm{OR} \mathrm{I})$. Zeit. Naturfosch. B 1981, 36, 431-433. [CrossRef]

21. Dineen, J.A.; Pauson, P.L. Some Cyclopentadienylcobalt cyanides and isocyanides. J. Organomet. Chem. 1972, 43, 203-207. [CrossRef]

22. Fiebig, L.; Kuttner, J.; Hilt, G.; Schwarzer, M.C.; Frenking, G.; Schmalz, H.-G.; Schäfer, M. Cobalt Catalysis in the Gas Phase: Experimental Characterization of Cobalt(I) Complexes as Intermediates in Regioselective Diels-Alder Reactions. J. Org. Chem. 2013, 78, 10485-10493. [CrossRef] [PubMed]

23. Chirila, P.G.; Whiteoak, C.J. Recent advances using $\left[\mathrm{Cp}{ }^{*} \mathrm{Co}(\mathrm{CO}) \mathrm{I}_{2}\right]$ catalysts as a powerful tool for C-H functionalisation. Dalton Trans. 2017, 46, 9721-9739. [CrossRef] [PubMed]

24. Ahmad, K.; Khan, B.A.; Roy, S.K.; Zain ul, A.; Mahmood, R.; Khan, J.; Ashraf, H. Theoretical insights on the C-C bond reductive elimination from Co(III) center. Comp. Theor. Chem. 2018, 1130, 140-147. [CrossRef]

25. Yamazaki, H.; Hagihara, N. Preparations and reactions of alkylcobalt complexes and diphenylacetylenecobalt complexes having a $\pi$-cyclopentadienyl group as a ligand. J. Organomet. Chem. 1970, 21, 431-443. [CrossRef]

26. Evitt, E.R.; Bergman, R.G. Substitution, alkyl-transfer, and thermal decomposition reactions of $\eta^{5}$-cyclopentadienyl(triphenylphosphine)dimethylcobalt(III). J. Am. Chem. Soc. 1980, 102, 7003-7011. [CrossRef]

27. Roglans, A.; Pla-Quintana, A.; Sola, M. Mechanistic Studies of Transition-Metal-Catalyzed [2 + $2+2]$ Cycloaddition Reactions. Chem. Rev. 2021, 121, 1894-1979. [CrossRef] [PubMed] 